\title{
A Two-Stage Theory of Discussant Influence on Vote Choice in Multi-Party Systems
}

\author{
RÜDIGER SCHMITT-BECK and JULIA PARTHEYMÜLLER*
}

\section{$\underline{\text { Abstract }}$}

We address two aspects of social network influence on voters' electoral choices that are not well understood: the role of party systems as institutional contexts, and the relationship between social pressure and information sharing as mechanisms of influence. We argue that in the cleavage-based multi-party systems of Western Europe discussant influence at elections occurs in two stages. First, discussants constrain voters to opt for parties from the same ideological camp by means of social pressure. Second, by providing information discussants influence which parties voters eventually choose out of these restricted 'consideration sets'. We test these assumptions using a panel survey conducted at the 2009 German federal election. The first proposition is clearly confirmed, for the second proposition evidence is supportive, although less unequivocally.

\footnotetext{
* University of Mannheim (schmitt-beck@uni-mannheim.de). For important inspiration and support in preparing this paper we are indebted to Hans Hassell, Josephine Hörl, Oana Lup, Patricia Moy, Thomas Plischke, Thomas Poguntke, Anne Schäfer, Richard Traunmüller, Bernhard Weßels, Line Winterhoff as well as three anonymous reviewers. The data used in this paper are available for free download at http://www.gesis.org/gles. Do files for replicating the analyses are available from the authors.
} 


\section{$\underline{\text { Introduction }}$}

Voters' electoral choices do not develop in a social vacuum. When making up their minds about which candidate or party to support at the ballot box, citizens refer to the members of their social networks. Experiencing disagreement over electoral preferences with other persons stimulates them to reconsider their decisions. Often this leads voters to adapting their preferences to those of their discussants. As a consequence voting behaviour appears contagious. This 'social logic' of voting ${ }^{1}$ has been demonstrated by numerous studies. ${ }^{2}$ While this thriving literature has made unequivocally clear that the phenomenon of discussant influence at elections is a substantive one, it is in various ways not yet well understood. This paper addresses two questions extant research has not yet solved: how discussant influence works in the specific context of West European multi-party systems, and how social pressure and information sharing relate to one another as mechanisms of discussant influence.

Studies on discussant influence have rarely addressed issues of institutional context. Most analyses of voters' electoral interdependence focused on candidate voting in the American two-party system. Only few studies have been conducted in countries with multiparty systems, and they have usually construed electoral influence in the same way as American studies. With few exceptions this research thus failed to take the more complex conditions of party competition and choice in such systems into account. ${ }^{3}$

\footnotetext{
${ }^{1}$ Zuckerman 2005.

${ }^{2}$ E.g., Campus, Pasquino and Vaccari 2008; Huckfeldt et al. 1995; Huckfeldt, Johnson and Sprague 2004; Huckfeldt and Sprague 1991, 1995; Ikeda 2010; Johnston and Pattie 2006, 127-43; Knoke 1990; Levine 2005; Magalhães 2007; Pattie and Johnston 2000, 2001, 2002; Richardson and Beck 2007; Schmitt-Beck 2000, 2004; Sinclair 2012; Zuckerman, Dasovic and Fitzgerald 2007.

${ }^{3}$ For a rare exception, referring to the Japanese multi-party sytem, see Ikeda and Richey 2009.
} 
In the two-party system of the United States, political competition is dualistic and confrontational. Electoral disagreement between a voter and a discussant inevitably means being on different sides of the fence, and therefore entails antagonism and discord. ${ }^{4}$ In West European multi-party systems party competition is more complex. Reflecting socio-political cleavages, these systems are structured in polar ideological camps ${ }^{5}$ or directions ${ }^{6}$ which usually contain several different parties. Accordingly, voters can experience at least two different types of electoral disagreement with their discussants, depending on whether it concerns parties from the same or the opposing ideological camp. The latter type is dualistic and therefore resembles antagonistic disagreement in the American sense. But the former concerns ideologically adjacent parties which differ in details, but share fundamental political values and sometimes even form electoral alliances. In such cases, disagreement between voters and discussants can be assumed to be considerably less intense, and the resulting conflict (if any) to be less divisive. That disagreement in multi-party systems is thus a matter of degrees may have important implications for discussant influence which have not yet been addressed by extant research.

The second shortcoming addressed by our paper concerns the mechanisms of discussant influence. While it is clear that voters often adapt their electoral preferences to those of their discussants, it is a matter of dispute why they do so. To explain the influence of social networks on voting behaviour two competing lines of theorizing have been proposed. One emphasizes cognitive processes of information sharing between voters, the other affectladen processes of social pressure and conformity. ${ }^{7}$ Available evidence suggests that there is some truth to both the social pressure and the information sharing perspective. However, the

\footnotetext{
${ }^{4}$ Klofstad, Sokhey and McClurg 2013.

${ }^{5}$ Bartolini and Mair 1990.

${ }^{6}$ Rabinowitz and Macdonald 1989.

${ }^{7}$ Ikeda 2010; Leighley 1990; Sinclair 2012, 7-12.
} 
relationship between them is unclear. While many studies have adopted one or the other perspective as untested premise of their research ${ }^{8}$, attempts to identify which of them describes better the influence taking place in voters' social networks have been rare ${ }^{9}$, and none has thus far investigated conditions under which one or the other of the two mechanisms prevails.

With regard to both shortcomings of current research we seek to break new ground by proposing a two-stage theory of discussant influence. For the specific context of West European multi-party systems it states under which conditions which of the two approaches better captures the influence process taking place. It maintains that in these systems both mechanisms are important, although to varying degrees at different stages of layered decision processes that begin long before elections. We contend that on the long run and mainly by means of continuous normative pressure discussants restrict the party alternatives taken into account by voters to ideologically coherent 'consideration sets', whereas the ultimate choices of particular parties out of these pre-filtered sets at specific elections are more strongly guided by information obtained during campaigns through social communication. We attempt to test this theory for the case of the 2009 German federal election.

The following sections develop the two-stage theory of discussant influence in more detail and derive testable hypotheses. Next, we outline our research strategy, including technical information on the data used and the variables included in our models. The subsequent section presents our results and interprets them in the light of our hypotheses. In the final section we summarize our findings and discuss their implications.

\section{$\underline{\text { Discussant influence at elections }}$}

\footnotetext{
${ }^{8}$ E.g., Berelson, Lazarsfeld and McPhee 1954; Lazarsfeld, Berelson and Gaudet 1968; Huckfeldt, Johnson and Sprague 2004; Huckfeldt and Sprague 1995; Zuckerman, Dasovic and Fitzgerald 2007.

${ }^{9}$ Sinclair 2012.
} 
While scholars of electoral behaviour have long neglected voters' interdependence at elections, ${ }^{10}$ during the past two decades numerous studies have demonstrated its relevance beyond reasonable doubt. However, while it is clear that voters adjust their preferences to those of their discussants it is less clear why they do so. Two competing explanations have been proposed to make sense of this phenomenon: information sharing and social pressure. ${ }^{11}$

The first perspective is inspired by Downs' view of voters as instrumental seekers of cost-efficient information on which they can base their electoral choices. ${ }^{12}$ Here, discussant influence at elections is thought to come about as a consequence of voters' search for electoral orientation, the provision of information by other persons, and ensuing processes of learning on the part of voters. Social communication is believed to affect electoral decisions by providing voters with useful electoral guidance. ${ }^{13}$ While this theory implies that discussant influence has essentially cognitive roots, the competing view emphasizes rather unpolitical affective processes relating to individuals' interest in the stability of their social ties. ${ }^{14}$ It dates back to the classic Columbia studies ${ }^{15}$ and conceives of voters as human beings that are inherently social and place a high value on maintaining harmonious relationships with their peers. ${ }^{16}$ According to this perspective, normative group pressure leads to behavioural conformity on the part of individuals which adopt the preferences of others in order to avoid damaging their mutual relationship. ${ }^{17}$

\footnotetext{
${ }^{10}$ For an intellectual history of the 'social logic' of voting cf. Zuckerman, Dasovic and Fitzgerald 2007, 1-31.

${ }^{11}$ Ikeda 2010; Leighley 1990; Sinclair 2012, 7-12.

${ }^{12}$ Downs 1965, 207-37.

${ }^{13}$ Huckfeldt and Sprague 1995; Zuckerman, Dasovic and Fitzgerald 2007.

${ }^{14}$ Cf. Abrams, Iversen and Soskice 2011.

${ }^{15}$ Berelson, Lazarsfeld and McPhee 1954; Lazarsfeld, Berelson and Gaudet 1968.

${ }^{16}$ For a general discussion of humans' 'need to belong' cf. Baumeister and Leary 1995.

${ }^{17}$ Sinclair 2012.
} 
Many studies in the field have not bothered with theoretical reasoning on mechanisms by which discussant influence may come about but contented themselves with demonstrating its existence. Others have adopted either social pressure ${ }^{18}$ or information sharing ${ }^{19}$ as explicit, though untested theoretical premises. Only recently researchers, most notably Sinclair in her study of American elections, ${ }^{20}$ started to investigate which of the competing views better describes the influence actually taking place in social networks.

How can one decide whether one or the other of the two mechanisms is more appropriate in order to understand discussant influence? According to Sinclair, leverage to solve this problem can be gained by inspecting how attributes of discussants and of their relationships to voters moderate their influence. ${ }^{21}$ Each of the two theories implies specific expectations with regard to factors that should facilitate or impede discussant influence. For instance, if it comes about as a result of social pressure it should vary depending on the intimacy of the relationship between voter and discussant. ${ }^{22}$ More powerful influence in primary relationships that are characterized by a climate of confidence, emotional appreciation and mutual regard as well as a high density of interaction indicates the operation of social pressure and conformity. Some studies have indeed reported discussant influence on electoral preferences to be particularly intense between spouses, followed by other family

\footnotetext{
${ }^{18}$ E.g., Berelson, Lazarsfeld and McPhee 1954; Lazarsfeld, Berelson and Gaudet 1968.

${ }^{19}$ E.g., Huckfeldt, Johnson and Sprague 2004; Huckfeldt and Sprague 1995; Zuckerman, Dasovic and Fitzgerald 2007.

${ }^{20}$ Sinclair 2012.

${ }^{21}$ Sinclair 2012, 12-3, 105-7, 151-3.

${ }^{22}$ Berelson, Lazarsfeld and McPhee 1954; Lazarsfeld, Berelson and Gaudet 1968; McClosky and Dahlgren 1959; Lazer et al. 2010; Sinclair 2012.
} 
bonds and friendships. Compared to these 'strong' ties, secondary relationships like neighbours and co-workers appear less conducive to discussant influence. ${ }^{23}$

In contrast, from the point of view of the information sharing model 'it is the message that has the potential to persuade, not the messenger'. ${ }^{24}$ Whereas simple cues during everyday interactions should be sufficient for triggering the social pressure mechanism, information sharing effects can only come about as a 'consequence of explicit social communication'. ${ }^{25}$ In line with this 'conversion through conversation' hypothesis ${ }^{26}$ a discussant's influence on a voter should vary in accordance to certain characteristics of the communication taking place between them. Available evidence indicates that there is some truth to this perspective, too. For instance, studies found discussants to be more influential when engaging in frequent political talks with voters, ${ }^{27}$ and when communicating their views effectively, that is, so clearly that they are easily discernible by their addressees. ${ }^{28}$ Other research suggests that network partners are more influential when they are perceived by voters to be knowledgeable about political matters and trustworthy in the sense of having basically similar political views. ${ }^{29}$ These are exactly the attributes emphasized by Downs and more recently Lupia and McCubbins as qualities that should make discussants particularly attractive to voters as sources of electoral advice. $^{30}$

\footnotetext{
${ }^{23}$ Huckfeldt and Sprague 1995; Levine 2005; Schmitt-Beck 2000; Zuckerman, Dasovic and Fitzgerald 2007; Lazer et al. 2010; Sinclair 2012.

${ }^{24}$ Sinclair 2012, 10.

${ }^{25}$ Sinclair 2012, 2.

${ }^{26}$ Johnston and Pattie 2006, 127.

${ }^{27}$ Kenny 1998; Kenny 1994; Knoke 1990; Schmitt-Beck 2000, 257-320.

${ }^{28}$ Huckfeldt, Johnson and Sprague 2004, 68-97.

${ }^{29}$ Huckfeldt 2001; Huckfeldt and Sprague 1995; Johnston and Pattie 2006, 136-7; Kenny 1998; Kenny 1994; Levine 2005; Richey 2008; Schmitt-Beck 2000, 280-5.

${ }^{30}$ Downs 1965, 230-3; Lupia and McCubbins 1998.
} 
Hence, there is not only evidence in support of the social pressure model of discussant influence, but also of the information sharing model. How these findings can be theoretically reconciled is unclear. In the following we propose an answer to this question for the specific context of West European multi-party systems. In contrast to previous studies it does not construe the two perspectives as competitive, but as complementary. Conceding that influence processes can be characterized by both mechanisms, it specifies conditions under which one or the other of them can be expected to dominate.

\section{Electoral choices in multi-party systems}

Compared to candidate elections in the American two-party system, parliamentary elections in West European multi-party systems are more complex, layered contests. Whereas in the United States each vote gained by one of the candidates is one lost for its (usually) sole competitor, elections in Western Europe are characterized by competition between two cleavage-based ideological camps at one level, and between parties of the same ideological direction within camps at the other. ${ }^{31}$ In the former case the contest is 'between enemies on different sides of the cleavage boundary', in the latter 'between friends in the same cleavage block'. ${ }^{32}$ According to the directional theory of voting this contrast is reflected in the way voters look at elections. For them, it makes a fundamental difference whether the parties that compete for their votes belong to the same or to opposing ideological camps. ${ }^{33}$ Competition between parties of opposing ideological directions is antagonistic and insofar resembles the dualism of American electoral contests. In contrast, competition between parties of the same ideological camp concerns alternatives that share important basic values and is thus rather a

\footnotetext{
${ }^{31}$ Van der Eijk and Franklin 2009, 87-117.

${ }^{32}$ Bartolini and Mair 1990, 3.

${ }^{33}$ Rabinowitz and Macdonald 1989; see also Baldassari 2013, 70; Zakharova and Warwick 2014.
} 
matter of degrees. In fact, such parties often campaign as proto-coalitions, coordinate their electioneering, and form governments together when they obtain a joint majority.

Some recent studies have sought to take these conditions into account by modelling electoral decision making in multi-party systems as a two-stage process of funnelling down alternatives to the eventual choice. ${ }^{34}$ They start from the psychological premise that in choice situations with multiple alternatives decision processes are more complex than under conditions of simple binary choices. Their inspiration comes from psychological social judgment theory ${ }^{35}$ and marketing research ${ }^{36}$. They assume that voters come to grips with this complexity by first forming a consideration set consisting of a limited number of parties that are deemed in principle electable. It is further assumed that the party eventually supported at the ballot box is chosen in a second step out of this pre-filtered reservoir of alternatives.

Research on stepwise decision making generally suggests that in the first stage noncompensatory, heuristics-based decision strategies are used for narrowing down the range of alternatives. This implies that only alternatives possessing certain characteristics are kept under consideration whereas those lacking them are immediately excluded. ${ }^{37}$ Regarding vote choices, this means that only parties sharing one or at most a small number of core characteristics have a chance to remain in the consideration set. Several studies of West European elections have shown that left-right ideology is crucially important for circumscribing individuals' consideration sets. ${ }^{38}$

\footnotetext{
${ }^{34}$ De Vries and Rosema 2008; Karlsen and Aardal 2012; Oscarsson, Gilljam and Granberg 1997; Paap et al. 2005; Plischke and Bergmann 2012; Plischke 2014; Shikano 2003; Steenbergen and Hangartner 2008; Wilson 2008.

${ }^{35}$ Sherif and Hovland 1961.

${ }^{36}$ Roberts and Lattin 1991; Shocker et al. 1991.

${ }^{37}$ Gertzen 1992.

${ }^{38}$ Karlsen and Aardal 2012; Oscarsson, Gilljam and Granberg 1997.
} 
When it comes to choosing a party out of this constrained set of alternatives, a different mechanism kicks in. It appears to be more strongly guided by cognitive processes. Picking a party from a restricted range of alternatives that do not differ much from one another in their basic directional orientation requires more careful and detailed scrutiny of the available options. The final choice is therefore assumed to be taken more carefully by means of compensatory strategies for evaluating and ordering the remaining alternatives. ${ }^{39}$ This requires more thorough and systematic thinking which in turn presupposes a sufficient base of rather specific and detailed political information. This may concern short-term factors related to the current election like leaders' personalities, recent political events or the issues of the day, ${ }^{40}$ but also parties' electoral prospects, programmatic platforms and coalition signals which electors need to refer to when aiming to cast their votes strategically. ${ }^{41}$

The first step of decision making which leads to the exclusion of parties from consideration sets thus appears rather simple and refers mainly to the basic heuristic of ideological direction. In contrast, choosing a single party out of a limited set of alternatives that resemble each other in their fundamental political values and vary only in details implies more differentiated cognitive processes. It also requires rather specific electoral information. In the following we propose that discussant influence plays a role at each of these stages of electoral decision making, although in different ways - primarily via social pressure at the first stage, and more strongly by means of information sharing at the second.

\section{A two-stage theory of discussant influence at elections in multi-party systems}

\footnotetext{
${ }^{39}$ Gertzen 1992.

${ }^{40}$ Karlsen and Aardal 2012; Oscarsson, Gilljam and Granberg 1997; Plischke and Bergmann 2012.

${ }^{41}$ Bytzek and Roßteutscher 2011; Meffert et al. 2011.
} 
It is commonly assumed that processes of discussant influence at elections are set in motion when voters experience disagreement over electoral preferences with members of their social networks. Interacting with a discussant supporting another candidate or party than themselves stimulates voters to reconsider and ultimately adapt their preferences. ${ }^{42}$ In American research disagreement over candidate preferences is typically equated with political discord and conflict. ${ }^{43}$ Conversations with nonlike-minded individuals have accordingly been characterized as 'dangerous', in contrast to interactions with like-minded persons which are 'safe'. ${ }^{44}$ Obviously this understanding of electoral disagreement makes good sense in the context of an inherently dualistic two-party system like the one of the United States where most existing research on discussant influence at elections has been conducted. At American elections there are usually only two contenders, and the winner takes all. The essence of electoral disagreement can thus be efficiently expressed by the simple formula that whoever is not with me is against me.

In a multi-party system, however, being exposed to a discussant that supports another party than oneself can mean different things, depending on whether this party belongs to the same or the opposing ideological camp. For such contexts we therefore propose to distinguish between two types of electoral disagreement. The first concerns the ideological direction of parties: Does a discussant support a party from the same side or from across the ideological divide? The second type of disagreement is nested within the first one: If a discussant prefers a party from the same spectrum as a voter, is it the same party or a different one?

Most studies of discussant influence in European multi-party systems have ignored these complexities and simply adopted the American approach. They determined electoral disagreement by distinguishing whether voters supported the same or any other party than

\footnotetext{
${ }^{42}$ Huckfeldt and Sprague 1995; McPhee, Ferguson and Smith 1963.

${ }^{43}$ Klofstad, Sokhey and McClurg 2013.

${ }^{44}$ Eveland and Hively 2009.
} 
their discussants. ${ }^{45}$ Some studies also chose to focus on party blocks instead of single parties for determining electoral agreement and disagreement. They referred to criteria such as incumbency and opposition, ${ }^{46}$ electoral alliances ${ }^{47}$ or ideological camps. ${ }^{48}$ These studies recognized that in West European party systems party blocks are a functional equivalent to single parties in the American two-party system. However, they neglected that discussant influence might also play a role for choices between parties from the same blocks. Moving beyond this research our theory of discussant influence in multi-party systems offers an approach for dealing with the fact that under such conditions electoral disagreement is a matter of degrees.

At its core is the claim that both types of electoral disagreement - between party blocks and between parties from the same block - trigger processes of discussant influence, although in different ways at different stages of the funnel-shaped decision-process outlined above. Whether the parties supported by voters' discussants are ideologically congruent or incongruent to their own preferences can be assumed to be crucial for the formation and maintenance of ideologically coherent consideration sets. In contrast, whether a discussant prefers the same party as a voter or another party from the same ideological camp should make a difference for the ultimate selection of a particular party out of this choice set. Importantly, we further assume that different mechanisms of discussant influence characterize the two stages. We expect social pressure to be more important for filtering down electoral alternatives to ideologically consistent consideration sets. Information sharing should be especially relevant for making up one's mind about which party ultimately to choose out of a consideration set. We see the first stage rather as a long-term process based on continuous

\footnotetext{
${ }^{45}$ E.g., Hopmann 2012; Huckfeldt, Ikeda and Pappi 2005; Schmitt-Beck 2000.

${ }^{46}$ Magalhães 2007.

${ }^{47}$ Campus, Pasquino and Vaccari 2008.

${ }^{48}$ Lup 2010; Coffé and Need 2010.
} 
social interaction and potentially spanning entire electoral cycles. The latter we assume to be rather short-term and primarily driven by voters' political conversations during campaigns.

Basic ideological leanings to the left or right are important elements of many West Europeans' political identity ${ }^{49}$ and thus carry a significant affective flavour ${ }^{50}$. We therefore assume that social pressure is a major reason for the ideologically uniform structure of consideration sets. Especially within their intimate relationships discussants will tend not to take it lightly if a voter deviates from their basic political value orientation in his or her electoral behaviour. As a consequence, many individuals will find themselves confronted with external social norms signalling that persons whom they hold in high esteem are not inclined to tolerate them straying from the 'fold to which they belong'. ${ }^{51}$ By threatening them with withdrawal from a relationship voters do not want to see damaged, spouses, relatives and friends can exert substantial influence on these persons' decision making at elections.

Research into discussant influence on partisanship supports this argument. In one of the few studies that compared discussant influence on partisanship and candidate evaluations at an election, MacKuen and Brown ${ }^{52}$ found American voters' partisanship to be strongly constrained by the party identifications of their friends. They concluded from their research that a 'political self-definition [...] represents a [...] serious matter. Conversational content is not sufficient to generate change; instead, individuals respond to their friends' fundamental loyalties. This pattern suggests that self-identification depends on imitative rather than cognitive learning, with the citizen adopting friends' characters rather than reacting to what friends say'. ${ }^{53}$ In West European multi-party systems cleavage-based ideological identities

\footnotetext{
${ }^{49}$ Dalton, Farrell and McAllister 2011.

${ }^{50}$ Baldassari 2013, 70; Sniderman, Brody and Tetlock 1991, 140-63.

${ }^{51}$ Lazarsfeld, Berelson and Gaudet 1968, 73.

${ }^{52}$ MacKuen and Brown 1987.

${ }^{53}$ MacKuen and Brown 1987, 484.
} 
fulfil partly equivalent functions to partisanship in the United States. ${ }^{54}$ It can thus be assumed that citizens similarly strongly care about their close associates' fidelity to parties from either the ideological left or right. By means of affect-laden normative pressure they consequentially constrain voters to parties from the same ideological spectrum.

On the other hand, discussants can be assumed to take a more relaxed stance with regard to which party is eventually chosen from this limited set. This is no longer about a polar confrontation between contradictory worldviews but about details and degrees on the basis of a fundamental correspondence with regard to basic political values. Therefore, at this stage the value of discussants as providers of cost-efficient information should come to the fore. When analyzing discussant influence on voters' candidate evaluations MacKuen and Brown found that '[c]urrent, transitory, information plays the greatest part in influencing attitude change'. ${ }^{55}$ According to their research, voters' candidate attitudes were not responsive to their friends' basic political loyalties, but rather to 'hot communication - that is, the content of currently ongoing conversations, whether they reflect stable political biases or not'. ${ }^{56}$ This suggests that in Western Europe discussant influence with regard to choosing a party out of a consideration set occurs by way of information sharing rather than social pressure.

In sum, we assume discussant influence at elections in West European multi-party systems to take two different forms, corresponding to successive stages of decision making. We expect social pressure to be more important with regard to the first stage that limits voters to parties from the same ideological spectrum as they will conform to the behavioural norms to which they are exposed by their discussants. We further expect information sharing to be relevant mainly at the ensuing stage when voters make up their minds about which parties to choose out of their consideration sets.

\footnotetext{
${ }^{54}$ Fleury and Lewis-Beck 1993; Shively 1972; van der Eijk and Niemöller 1983.

${ }^{55}$ MacKuen and Brown 1987, 484.

${ }^{56}$ MacKuen and Brown 1987, 472.
} 


\section{$\underline{\text { Hypotheses }}$}

The remainder of this paper aims at providing evidence for our contention that in ideologically structured multi-party systems like those of Western Europe both social pressure and information sharing are important mechanisms of discussant influence, although to varying degrees at different stages of electoral decision processes. To gain leverage for substantiating this claim empirically we refer to patterns of discussant influence that are characteristic for each of the two mechanisms. ${ }^{57}$ If discussant influence came about as a result of social pressure exerted by a discussant on a voter it should vary by the intimacy of the relationship between these individuals. ${ }^{58}$ Since we expect social pressure to be especially important as a mechanism of discussant influence at the first stage of decision making, when discussants constrain the range of alternatives taken into consideration for possible electoral support by voters, we propose the following testable hypothesis:

H1: Discussant influence is stronger for primary relationships, most notably for spouses, followed by relatives and friends, than for secondary relationships. These differences between relationships are more pronounced at the first than at the second stage of decision making.

If characteristics of the social communication taking place between a discussant and a voter moderate the influence exerted by the discussant, information sharing is its likely explanation. ${ }^{59}$ This may concern the frequency and clarity of such communication as well as how voters perceive their discussants with regard to their expertise and trustworthiness as

\footnotetext{
${ }^{57}$ Cf. Sinclair 2012, 12-3.

${ }^{58}$ Sinclair 2012, 12.

${ }^{59}$ Cf. Sinclair 2012, 8-10.
} 
political information sources. Since we assume that information sharing is especially important at the second stage of decision making, when discussants influence which parties voters choose from those contained in their ideologically coherent consideration sets, we hypothesize:

$\mathrm{H} 2 \mathrm{a}:$ A discussant's influence is higher the more often he or she discusses political matters with a voter. This effect is more pronounced at the second than at the first stage of decision making.

$\mathrm{H} 2 \mathrm{~b}$ : A discussant's influence is higher the more effectively he or she communicates his or her electoral preference to a voter. This effect is more pronounced at the second than at the first stage of decision making.

H2c: A discussant's influence is higher the more knowledgeable in political matters he or she is perceived to be by a voter. This effect is more pronounced at the second than at the first stage of decision making.

$\mathrm{H} 2 \mathrm{~d}$ : A discussant's influence is higher the more trustworthy in political matters he or she is perceived to be by a voter. This effect is more pronounced at the second than at the first stage of decision making.

$\underline{\text { Data and Methods }}$

Data

An excellent case for testing our hypotheses is Germany. Its party system is rooted in sociopolitical cleavages and structured ideologically and by party size ${ }^{60}$ Parties look back at long traditions of representing the interests of particular social groups which are reflected in

\footnotetext{
${ }^{60}$ Niedermayer 2006.
} 
distinct positions on the left-right axis of ideological identities. ${ }^{61}$ All five parties represented in the national legislature (Bundestag) can be located on the right or left side of the ideological spectrum. Each direction is represented by one larger and one or two smaller parties. The system's gravitation centres are the Christian Democrats (CDU/CSU) and the Social Democrats (SPD), two large parties of the centre-right or centre-left respectively. They represent opposing sides of the two major historical cleavages of German society, religion and class. All federal governments since 1949 have been led by one of these two parties. Like the CDU/CSU, the market-liberal FDP is located on the right side of the ideological conflict axis. The Greens and the Left, on the other hand, are both located to the left of the SPD.

The parties' left-right placements are reflected in their election manifestoes, ${ }^{62}$ and voters are well aware of them. ${ }^{63}$ Ideological directions are also an important driving force behind the parties' politics of coalition-building, ${ }^{64}$ both with regard to proto-coalitions during campaigns and actually formed governments. Since the 1980s the main confrontation has been between a 'bourgeois' or 'black-yellow' coalition of Christian Democrats and Liberals (FDP) and a 'red-green' alliance of Social Democrats and Greens. ${ }^{65}$ During the past decades

\footnotetext{
${ }^{61}$ Knutsen 1995.

${ }^{62}$ Bytzek and Roßteutscher 2011.

${ }^{63}$ Dalton, Farrell and McAllister 2011, 134; Neundorf 2012; Roßteutscher and Scherer 2011.

${ }^{64}$ E.g., Martin and Stevenson 2001.

${ }^{65}$ CDU/CSU and FDP have governed the country from 1983 to 1998 and again since 2009, SPD and Greens from 1998 to 2005 . The 2005 to 2009 electoral period is partly an exception. After a polarized campaign that once again sharply pitted the traditional alliances against each other at the 2005 federal election none of them reached a majority of seats so that a grand coalition between the two large parties was the only feasible option. However, it was always clear that neither of the involved parties sought a continuation of this collaboration.
} 
electoral competition in Germany has thus been strongly structured by ideological confrontations, pitting two camps - one left, one right - against each other. ${ }^{66}$

Our analysis is based on a pre- and post-election panel survey conducted as part of the 2009 German Longitudinal Election Study (GLES). A random sample of 6,008 German citizens aged 18 and above was interviewed by telephone during the campaign of the 2009 German federal election, of which about two thirds were reinterviewed after the election $(\mathrm{N}=$ 4,027). ${ }^{67}$ The pre-election wave contained a sequence of questions developed especially for the purpose of efficiently mapping respondents' political core discussion networks ${ }^{68}$ in the context of a national election study. It prompted respondents' most important political discussion partners, and elicited perceptional data for up to two discussants. ${ }^{69}$

\footnotetext{
${ }^{66}$ The Left has thus far only participated in SPD-led coalitions at the state level, but has not been deemed acceptable as a coalition partner at the federal level. This is a peculiarity of German politics in the aftermath of German unification, since the Left is a successor organization of the former East German socialist state party SED and pursues rather fundamentalist policy stances.

${ }^{67}$ Rattinger, Hans, Sigrid Roßteutscher, Rüdiger Schmitt-Beck and Bernhard Weßels: German Longitudinal Election Study, Component 2: Rolling-Cross-Section-campaign study with post-election panel wave (ZA5303, version Pre1.6). Field period: 29 July to 26 September, 2009. The data are accessible for free download at http://www.gesis.org/gles.

${ }^{68}$ Marsden 1987.

${ }^{69}$ The network generator was preceded by a question on the general frequency of discussions 'with other persons, such as family members, friends or acquaintances, about the parties and the federal election' which filtered off all non-discussants. Those discussing politics were asked: 'If you think of the person to whom you talked most often during the past week about the parties or the federal election, what is your relationship to that person - is it your spouse or partner, a relative, a friend, a co-worker or a neighbor?' Respondents were then asked to assess this discussant's political expertise, degree of opinion congruence in political conversations and perceived vote intention for which response latencies were registered in addition to verbal responses.
} Subsequently, respondents were asked if there were other persons with whom they also discussed 'about the 
Our analysis applies a dyadic perspective. Its unit of analysis are pairs of voters and discussants. ${ }^{70}$ Our active dataset is restricted to cases for which our research question is substantially meaningful, that is, those dyads where the respondent in the pre-election wave perceived a preference for one of the five parties present in the federal parliament on the part of his or her discussant, and at the same time him- or herself also stated an intention to vote for one of these parties or was undecided. Obviously, respondents not engaging in any political conversations and thus without anyone who might influence them could not be included in the analysis. For the same reason dyads where respondents did not receive partisan communications from discussants had to be excluded..$^{71}$ Dyads where respondents were likely or certain non-voters could also not be included in the models. The resulting number of dyads available for the cross-sectional analyses is 3,661 and 2,757 for the panel analyses (corresponding number of respondents: 2,581 and 1,930$){ }^{72}$

parties or the federal election'. If so, for that person of the remaining group with whom they discussed politics most often the same question sequence was passed.

${ }^{70}$ Cf. Huckfeldt, Johnson and Sprague 2004; Huckfeldt and Sprague 1995.

${ }^{71}$ This concerns discussants perceived as non-voters as well as discussants of whose party preference respondents were unaware ('don't know' answers) or who were perceived as being undecided. Research on turnout effects of discussants found respondents with such discussants to be statistically indistinguishable from voters without any discussants (Partheymüller and Schmitt-Beck 2012). Still, the possibility cannot be ruled out that discussants perceived as non-voters might send potentially influential partisan messages to voters. However, discussants' perceived abstention was elicited by the party preference question (cf. footnote 73) and our data do not contain any other measures of possible partisan leanings. We therefore cannot investigate the possibility that non-voting discussants might be influential with regard to party choice.

${ }^{72}$ The various conditions resulting in the exclusion of cases from the analyses concerned varying shares of respondents and were in effect partly overlapping. The most important condition was abstention from political conversations which was the case for 34 percent of all respondents. Six percent indicated to be non-voters, two percent aimed to vote for one of the small non-parliamentary parties. 15 percent were not aware of a party preference on the part of any of their discussants or perceived them to be non-voters. One percent of the 


\section{Dependent variables}

Our analysis includes four dependent variables, two of them cross-sectional, based on preelection data on vote intentions, and two with a pre-post-election panel structure, taking into account respondents' actual party choices. They are based on comparisons between discussants' perceived pre-electoral party preferences ${ }^{73}$ and respondents' own vote intentions (cross-section) or recalled vote choices (panel). One cross-sectional and one panel variable register whether or not a voter favoured a party of the same ideological direction than the one supported by his or her discussant $(1=$ respondent prefers the same party or a party from the same ideological direction as the party favoured by the discussant, $0=$ respondent prefers a party from the opposite ideological direction as the party favoured by the discussant (preelection cross-sectional analysis also: discussant favours a party, respondent is undecided)). The two ideological camps consist of the parties situated right of centre (CDU/CSU and FDP), on the one hand, and the ones left of centre (SPD, Greens and Left), on the other. The other two dependent variables refer only to dyads that are homogenous in terms of parties' ideological direction and differentiate by whether or not voters supported the same party as their respective discussants $(1=$ respondent prefers same party as discussant, $0=$ respondent favours other party than discussant, but from same ideological direction (pre-election crosssectional analysis also: discussant favours a party, respondent is undecided)).

\footnotetext{
respondents had only discussants that supported one of the small non-parliamentary parties. Additional cases had to be dropped due to item non-response, mostly resulting from refusals to answer questions on respondents' own or on discussants' vote intentions or choices.

${ }^{73}$ The question read: 'For which party do you think this person will presumably vote at the federal election on 27 September, or do you think that he or she will stay home from the polls?'
} 
Strategy of analysis

A survey-based study of discussant influence like ours has to deal with a number of methodological challenges. Following Fowler et al. establishing causality requires safeguards against several potential fallacies. ${ }^{74}$ The first is unrepresentative egocentric network data. Smaller networks like those analysed in our study run the risk of unwarranted generalization to the entire universe of voters' politically relevant associates. Information on discussants beyond the second one has not been elicited in our study, and it is unclear whether findings are generalizable beyond the first and second discussants. However, comparative studies suggest that German voters' discussant networks are on average rather small. ${ }^{75}$ Moreover, our data display substantial variation on all discussant attributes relevant for our study (Table 1), and the distributions largely conform to those registered on the basis of network generators allowing for more discussants. ${ }^{76} \mathrm{We}$ are therefore confident that the information loss caused by truncated networks does not significantly bias our findings.

The second problem is misperception of discussant attributes. It concerns only those attributes where for theoretical reasons true rather than perceived states are expected to be relevant for political behavior ${ }^{77}$, in particular discussants' party preferences. ${ }^{78}$ Regarding discussants' electoral preferences American research based on snowball samples found some evidence of projection, leading to perceptions that are biased towards the respondents' own preferences. But overall accuracy has nonetheless been found to be quite high. ${ }^{79}$ Similar

\footnotetext{
${ }^{74}$ Fowler et al. 2011, 440-5.

${ }^{75}$ Cf. Schmitt-Beck 2000, 168.

${ }^{76}$ Cf. Schmitt-Beck 2000, 163-71.

${ }^{77}$ Fowler et al. 2011, 444.

${ }^{78}$ Huckfeldt, Johnson and Sprague 2004, 68-97.

${ }^{79}$ Huckfeldt and Sprague 1995, 124-145; Huckfeldt et al. 1998; Huckfeldt, Sprague and Levine 2000.
} 
findings have been recorded by German snowball studies, with one important difference:

German voters display a marked tendency to evade to 'Don't know' answers when in doubt about discussants' true electoral preferences. ${ }^{80}$ Dyads where this is the case cannot be included in our analysis. This diminishes the risk that our findings are confounded by projection.

Table 1: Descriptives for main independent variables

\begin{tabular}{|c|c|c|}
\hline Variables & $\begin{array}{l}\text { Pre-election cross- } \\
\text { section }\end{array}$ & $\begin{array}{c}\text { Pre-post election } \\
\text { panel }\end{array}$ \\
\hline \multicolumn{3}{|c|}{ Type of relationship (percent): } \\
\hline - Spouse or life partner & 30.5 & 31.2 \\
\hline - Relative & 23.6 & 23.4 \\
\hline - Friend & 26.8 & 27.0 \\
\hline - Co-worker & 13.7 & 12.9 \\
\hline - Neighbour & 2.9 & 2.8 \\
\hline - Other & 2.6 & 2.7 \\
\hline$(\mathrm{N})$ & $(3,657)$ & $(2,753)$ \\
\hline \multicolumn{3}{|l|}{$\begin{array}{l}\text { Most frequent discussant } \\
\text { (percent): }\end{array}$} \\
\hline - yes & 63.1 & 62.3 \\
\hline- no & 36.9 & 37.7 \\
\hline$(\mathrm{N})$ & $(3,661)$ & $(2,757)$ \\
\hline \multicolumn{3}{|c|}{ Response latencies (standardized): } \\
\hline - Mean & -0.1 & 0.0 \\
\hline$-\mathrm{SD}$ & 1.8 & 1.8 \\
\hline - Range & $-2.7-7.3$ & $-2.5-7.3$ \\
\hline$(\mathrm{N})$ & $(2,778)$ & $(2,097)$ \\
\hline \multicolumn{3}{|c|}{$\begin{array}{l}\text { Discussant political expertise } \\
\text { (percent): }\end{array}$} \\
\hline - Very low & 1.0 & 0.8 \\
\hline - Low & 13.8 & 14.0 \\
\hline - High & 53.7 & 53.6 \\
\hline - Very high & 31.4 & 31.7 \\
\hline$(\mathrm{N})$ & $(3,642)$ & $(2,745)$ \\
\hline \multicolumn{3}{|l|}{$\begin{array}{l}\text { Discussant political } \\
\text { trustworthiness (percent): }\end{array}$} \\
\hline - Often dissent & 19.6 & 19.6 \\
\hline - Sometimes dissent & 42.8 & 43.3 \\
\hline - Rarely dissent & 33.1 & 32.8 \\
\hline - Never dissent & 4.6 & 4.4 \\
\hline$(\mathrm{N})$ & $(3,645)$ & $(2,745)$ \\
\hline
\end{tabular}

${ }^{80}$ Pappi and Wolf 1984; Koßmann 1996; cf. also Schmitt-Beck 2000, 217. 
The third problem concerns the possibility of selection bias ${ }^{81}$, as a consequence of the homophily principle which predicts similar individuals to seek each other out as interaction partners. ${ }^{82}$ Either through politically motivated choices, or by accident as a by-product of selection on other attributes that are correlated with political affinities this may lead to electoral agreement between voters and discussants. However, several recent long-term studies suggest that at least the amount of direct political selectivity reflected in dyadic similarities is rather small in comparison to influence. For most people, politics does not seem to be a major concern in discussant choice, but once associated, members of social networks begin to converge in their party or candidate preferences. ${ }^{83}$ In addition, it must be kept in mind that the availability of like-minded associates depends on supply. Many voters will not be able to construct congenial networks despite trying, since selectivity is constrained by the composition of the contexts out of which discussants can only be chosen. ${ }^{84}$ Although not

\footnotetext{
${ }^{81}$ Shalizi and Thomas 2011.

${ }^{82}$ McPherson, Smith-Lovin and Cook 2001. In small networks dominated by more intimate ties like those we analyse this problem may be of particular concern.

${ }^{83}$ A year-long panel study which started its fieldwork before networks were even created demonstrated such a pattern for a sample of American college students (Lazer et al. 2010), Klofstad (2011) reported similar findings with regard to political participation. Bello and Rolfe (2014) analysed agreement in party preferences using panel data collected over nine months prior to the 2010 British general elections and found discussant influence to surpass selection considerably. Research on assortative mating has come up with mixed findings on selection and influence among spouses (Coffé and Need 2010; Alford et al. 2011; Klofstad, McDermott and Hatemi 2012, 2013). But strong long-term evidence in favour of influence instead of selection explanations of spousal similarity was provided by analyses of biennial panel data from the British and German household panel studies which trace how husbands' and wives' party attachments converged over periods of ten respectively 16 years (Zuckerman, Dasovic and Fitzgerald 2007, 71-90).

${ }^{84}$ Huckfeldt and Sprague 1995.
} 
unequivocal, the state of research is thus encouraging with regard to our interpretation of electoral agreement as a result of influence rather than selection.

Nonetheless, our analysis needs to take precautions against the possibility of reciprocal causation in order to build a strong case for the test of our theory of discussant influence. As McClurg recently pointed out, there is no single ideal solution to this problem, researchers can usually only resort to an approach 'akin to building a circumstantial case ${ }^{85}$ : to use the available data in a way that rules out alternative interpretations as far as possible, even if some residual ambiguity remains. In particular this requires controlling for demographic attributes and basic political orientations among respondents that may stimulate selectivity in the creation of social relationships ${ }^{86}$, although this strategy of course cannot be considered fully equivalent to randomization and experimental designs, since there is always the possibility of systematic confounders not included in the model because they are unmeasured or even unknown. As additional safeguard to reduce potential ambiguities of our findings, we therefore rely not only on cross-sectional but in particular also on panel analysis with lagged dependent variables when modelling social influence. The panel approach is much less vulnerable to both reciprocal causation and projection problems since it models not static relationships but change. ${ }^{87}$ The panel models essentially tell us which factors strengthen or weaken voters' likelihood to converge towards the preferences previously perceived on the part of their discussants. Since there was overall rather little turnover during the campaign (11 percent for the same camp condition, 8 percent of which were convergent; 16 percent for the same party condition, 10 percent of which were convergent), these models pose a particularly tough test for our hypotheses (see Table 2 for marginals). Arguably, they underestimate the true amount of electoral influence, since they register only short-term movements during the

\footnotetext{
${ }^{85}$ McClurg 2011, 358-9.

${ }^{86}$ Cf. Fowler et al. 2011, 443; Sinclair 2012, 80.

${ }^{87}$ Cf. Fowler et al. 2011, 444-5; Sinclair 2012, 80.
} 
last weeks of the campaign. This concerns in particular the hypothesized first stage of the decision process which we see as a continuous long-term process of which our panel data can provide only a quick snapshot. In contrast, the cross-sectional analyses indicate upper bounds of effect sizes, albeit with less certainty, as they are possibly more strongly affected by selection and projection bias.

Our analysis proceeds in three steps. Using probit analysis, we first model whether voters supported parties from the same or the opposite ideological camp as their respective discussants. In the second step we model the probability of supporting the same or different parties, given the same ideological direction. Dyads where voters and discussants favour parties from opposite ideological camps are excluded at this stage. ${ }^{88}$ To assess the validity of our hypotheses we need to compare these two models with regard to the strength of the estimated effects - this is the third and most important step of the analysis. All effects should be statistically relevant, but some of them rather in the first model, others in the second. In limited dependent variable models this is not as straightforward as in the linear model because the regression slopes may be affected by unobserved heterogeneity. ${ }^{89}$ Therefore, we calculate population averaged marginal effects (AME) and discrete differences following the observed-

\footnotetext{
${ }^{88}$ At first sight a Heckman selection model may seem to suggest itself for such an analysis. However, our data do not allow for the inclusion of an appropriate instrument variable to meet the exclusion restriction for a Heckman selection model. The lagged dependent variables of the two panel models are not identical which also precludes such a modelling strategy. Moreover, it must be borne in mind that the bias introduced by an incorrectly specified selection model may be severe and in fact be larger than the bias of a non-selection model even when selection is present (Brandt and Schneider 2007; Little 1985; Little and Rubin 1987).

${ }^{89}$ In limited dependent variable models assumptions are imposed on the distribution of the error in order to identify the mean and the variance of the latent variable. As a consequence the size of the $\beta$-coefficients depends on the actual size of the error variance, i.e. the amount of unobserved heterogeneity, and cannot be compared across different models or groups (Mood 2010).
} 
value approach as recommended by Hanmer and Kalkan. ${ }^{90}$ These quantities are not affected by unobserved heterogeneity ${ }^{91}$ and at the same time offer an intuitive interpretation, indicating the average increase in the probability of $\mathrm{Y}=1$ given a one-unit change in $\mathrm{X}$. In addition, from generating the marginal effects via the simulation method we automatically get bounds of uncertainty not merely for these quantities but also for derived differences in effects between the two models (differences and corresponding 95 percent confidence intervals are displayed in the last two columns of Tables 3 and 4). This allows us to test whether the impact of the various independent variables varies significantly between the models which represent the two stages of our process model.

Table 2: Party preferences in dyads

\begin{tabular}{lcccc}
\hline & \multicolumn{2}{c}{ Pre-election cross-section } & \multicolumn{2}{c}{ Pre-post election panel } \\
& $\mathrm{N}$ & $\%$ & $\mathrm{~N}$ & $\%$ \\
\hline $\begin{array}{l}\text { Same party } \\
\begin{array}{l}\text { Same camp, } \\
\text { different parties }\end{array}\end{array}$ & 1661 & 45.4 & 1329 & 48.2 \\
$\begin{array}{l}\text { Other camp } \\
\begin{array}{l}\text { Discussant party, } \\
\text { voter undecided }\end{array}\end{array}$ & 789 & 21.6 & 674 & 24.5 \\
\hline $\begin{array}{l}\text { Total (dyads) } \\
\text { Total } \\
\text { (respondents) }\end{array}$ & 3,661 & 21.5 & 754 & 27.4 \\
\hline
\end{tabular}

\footnotetext{
${ }^{90}$ To calculate the AME each of the other independent variables are held at their observed value (Hanmer and Kalkan 2013). The probability of $Y=1$ is calculated for each single respondent at the observed values reflecting his or her individual characteristics, and then averaged across all respondents.

${ }^{91}$ For a comparison and assessment of various measures using Monte Carlo simulation methods see Mood (2010).
} 
Independent variables

To test our hypothesis about the relevance of different types of relationship we include dummy variables into the models for the following relationships: spouses (including life partners), relatives and friends as primary relationships, and neighbours as well as the residual category of 'other' relationships as secondary relationships. Another secondary relationship, co-workers, serves as implied reference category. ${ }^{92}$ Our measure of the frequency of political conversations is a dummy variable indicating whether the respective discussant was the person to whom respondents talked most often about politics and thus was named first in the network (coded 1), or not $(0)$.

To test to what extent effective communication on the part of a discussant increases his or her electoral influence, we refer to response latencies with regard to respondents' reports on discussants' vote intentions, i.e. the time it took respondents to reproduce these preferences during interviews. A swift response to this question indicates easy accessibility of the respective discussant's vote intention in the respondent's memory. This measurement is based on the assumption that the unambiguousness of the discussant's electoral preference is reflected by the strength with which the mental concepts of a discussant and a party are associated in the long-term memory of a respondent. If a discussant expresses a party preference with great clarity a strong mental association between person and party can be established which can be easily - and thus quickly - retrieved during an interview. ${ }^{93}$

\footnotetext{
${ }^{92}$ Co-workers are the most frequent type of secondary relationships in our sample (cf. Table 1). More importantly, both an American study by Mutz and Mondak (2006) as well as comparative findings by SchmittBeck $(2000,231)$ suggest that the workplace is a context with a particularly high likelihood of encountering political disagreement. Hence, co-workers are optimal as contrast to the other types of relationships.

${ }^{93}$ Cf. Huckfeldt, Johnson and Sprague 2004, 76-85. Response times were registered in milliseconds by the interviewers. To control for the possibility of erroneous time measures interviewers were asked to assess whether
} 
Discussants' perceived political expertise is measured by means of a question asking how well the respective discussant was versed with regard to political matters $(0=$ not at all, 1 = not so well, 2 = well, 3 = very well). In line with Downs' and Lupia and McCubbins' claim that voters assess discussants as politically trustworthy if they share their general political worldviews we refer to respondents' overall assessments of the frequency of opinion differences during political conversations $(0=$ often, $1=$ sometimes, $2=$ rarely, $3=$ never $)$ for measuring discussants' perceived political trustworthiness. Dissent during political talks signals to a voter that this discussant is not on the same political wavelength and therefore should not be listened to, whereas its absence indicates that he or she is a political soul mate whose electoral advice can be confidently followed. ${ }^{94}$ Table 1 provides descriptives for all independent variables, based on the dyads available for the cross-sectional and for the panel analyses, respectively. It shows that panel attrition has affected the distributions remarkably little. $^{95}$

their measurements were valid. In addition we only consider such indications as valid which are within a range of two standard deviations above or below the mean response time for the analysed question. Furthermore the (validated) indications were standardized with reference to the individual baseline speed of each respondent, defined as a mental baseline speed of an individual which is independent from the specific content of a question. This was achieved by means of a bivariate regression of the target reaction time on the baseline reaction time which was determined as the overall time needed for the entire interview. The residuals of this estimation are used as response latency measures in the analyses (cf. Mayerl and Urban 2008.).

${ }^{94}$ Downs 1965, 230-3; Lupia and McCubbins 1998; see also Sinclair 2012, 7.

${ }^{95}$ Unsurprisingly, panel respondents were somewhat more educated and more interested in the election outcome than panel dropouts (panel respondents: 39 percent completed secondary education, 37 percent very strong interest; panel dropouts: 35 percent completed secondary education, 26 percent very strong interest). They also included a higher share of persons identifying with a party and voting in line with this attachment ( 50 percent vs 39 percent). We checked whether the findings reported below were robust to panel attrition by re-running the cross-sectional models only for respondents that took part in the post-election wave of the survey. The results of 


\section{Control variables}

Besides discussant influence electoral similarity between voters and their discussants can also be a consequence of actively seeking out like-minded discussants. Political predispositions in the sense of stable identities deeply rooted in voters' personalities are the most important potential motivators of political selectivity. To the degree associates are chosen on political terms, two types of identities can be expected to be of particular importance in Germany: partisanship and ideology. ${ }^{96}$ To control for the potential impact of party attachment we include in our models a dummy variable which indicates whether respondents supported a party at the ballots with which they identified (coded 1$)$, or not $(0=$ out-party voting, independent or undecided). ${ }^{97}$ To assess the role of ideological identification with regard to selectivity a standard left-right scale, folded at the midpoint, would be ideal. Unfortunately, this instrument is not available in our dataset. As a proxy we use a thermometer scale for respondents' feelings regarding a grand coalition as possible outcome of the upcoming this sub-group analysis were almost identical to those based on all first-wave respondents (see section A1 of the Online Appendix).

${ }^{96}$ Like in other West European democracies, partisanship and ideology in Germany developed as mental derivatives of the traditional anchoring of party competition in sociopolitical cleavages. Although initially rooted in the social categories from which these cleavages emerged and which they still mediate, they have over time become much more powerful than sociodemographic attributes as predictors of electoral behavior (cf., e.g., Weßels 2000; Thomassen 2005). When these two (interrelated) forms of political identity are taken into account it is difficult to conceive of additional factors that could plausibly be expected to give rise to political selectivity. As both predispositions are strongly related to electoral behaviour, including them as controls imposes a particularly tough test on any hypothesis stating other backgrounds of vote choice.

${ }^{97}$ The German standard instrument used for measuring partisanship is documented and discussed in Weisberg (1993, 724-6). Comparative research has shown that partisanship in Germany is similarly stable as in the U.S. and other countries (Schickler and Green 1997). 
election (scaled -5 to +5 ); using other data it can be shown that such an alliance between the parties dominating the two ideological camps is most popular among centrist voters. ${ }^{98}$

Political interest (five-point scale from $0=$ 'outcome of election considered as personally not important at all' to 4 = 'very important') is included to account for the reception and processing of campaign information from other sources than social communication. Moreover, the models contain a block of dummy variables indicating which party the respective discussant preferred (SPD, FDP, Greens, Left; implicit reference category: CDU/CSU). This accounts for differential opportunities to get in touch with supporters of parties in accordance to the parties' varying sizes. ${ }^{99}$ Furthermore, respondents' demographic characteristics age (in years), sex $(1=$ male, $0=$ female $)$ and education $(1=$ secondary education completed, $0=$ lower education level) are taken into account as control variables. Finally, the dependent variables of the cross-sectional models are added to the panel models as additional controls. ${ }^{100}$

\footnotetext{
${ }^{98}$ Using the GLES face-to-face pre-election study (Hans Rattinger, Sigrid Roßteutscher, Rüdiger Schmitt-Beck and Bernhard Weßels: German Longitudinal Election Study, Component 1: Pre-election cross-section (ZA5300, version 5.0.0). Field period: 10 August to 26 September, 2009) we validated this assumption by comparing the left-right positions of respondents ranking either the red-green coalition, the black-yellow coalition or the grand coalition best. According to this analysis those favoring the two within-camp coalition options are either more to the right (CDU/CSU-FDP) or to the left (SPD-Greens) of those favoring a block-straddling coalition of CDU/CSU and SPD (means 6.7, 4.5 and 5.6 on an 11-point left-right scale).

${ }^{99}$ Huckfeldt, Ikeda and Pappi 2005.

${ }^{100}$ Formally the models estimated in the first and second steps of our analysis can be specified as follows:

Cross-sectional models:

(1) Same camp: $\quad \operatorname{Pr}\left(Y_{\mathrm{ij}}^{\mathrm{Camp}, \mathrm{t}=0}=1\right)=\Phi\left(\alpha+\mathrm{D}_{\mathrm{P} \text { ijh }} \beta_{\mathrm{h}}+\mathrm{D}_{\mathrm{I} \mathrm{ijk}} \gamma_{\mathrm{k}}+\mathrm{C}_{\mathrm{R} \mathrm{il}} \delta_{\mathrm{l}}+\mathrm{C}_{\mathrm{D} \text { ijm }} \zeta_{\mathrm{m}}\right)$

(2) Same party within camp: $\operatorname{Pr}\left(\mathrm{Y}_{\mathrm{ij}}^{\mathrm{Party}, \mathrm{t}=0}=1\right)=\Phi\left(\alpha+\mathrm{D}_{\mathrm{P} \text { ijh }} \beta_{\mathrm{h}}+\mathrm{D}_{\mathrm{I} \text { ijk }} \gamma_{\mathrm{k}}+\mathrm{C}_{\mathrm{R} \text { il }} \delta_{\mathrm{l}}+\mathrm{C}_{\mathrm{D} \text { ijm }} \zeta_{\mathrm{m}}\right)$

Panel models:

(1) Same camp: $\quad \operatorname{Pr}\left(Y_{\mathrm{ij}}^{\mathrm{Camp}, \mathrm{t}=1}=1\right)=\Phi\left(\alpha+\mathrm{D}_{\mathrm{P} \text { ijh }} \beta_{\mathrm{h}}+\mathrm{D}_{\mathrm{I} \text { ijk }} \gamma_{\mathrm{k}}+\mathrm{C}_{\mathrm{R} \mathrm{il}} \delta_{\mathrm{l}}+\mathrm{C}_{\mathrm{D} \text { ijm }} \zeta_{\mathrm{m}}+\mathrm{Y}_{\mathrm{ij}}^{\mathrm{Camp}, \mathrm{t}=0} \eta\right)$

(2) Same party within camp: $\operatorname{Pr}\left(\mathrm{Y}_{\mathrm{ij}}^{\mathrm{Party}, \mathrm{t}=1}=1\right)=\Phi\left(\alpha+\mathrm{D}_{\mathrm{P} i \mathrm{jh}} \beta_{\mathrm{h}}+\mathrm{D}_{\mathrm{I} \mathrm{ijk}} \gamma_{\mathrm{k}}+\mathrm{C}_{\mathrm{R} \mathrm{il}} \delta_{\mathrm{l}}+\mathrm{C}_{\mathrm{D} \mathrm{ijm}} \zeta_{\mathrm{m}}+\mathrm{Y}_{\mathrm{ij}}^{\text {Party,t=0 }} \eta\right)$
} 


\section{$\underline{\text { Results }}$}

Discussant influence is highly conditional. Under some circumstances it becomes particularly pronounced, under others it is attenuated. ${ }^{101}$ From the specific patterns such conditionalities assume we can infer the relevance of the two mechanisms of discussant influence at the various stages of the decision process. ${ }^{102}$ Our expectation is that social pressure should be more evident at the first stage, when ideologically coherent consideration sets are formed, while patterns indicating effects of shared information should more strongly characterize the second stage, when a particular party is chosen out of this limited set of alternatives. Table 3 shows the results of the cross-sectional models, Table 4 the corresponding estimates from the panel models. Both tables contain the same two blocks of independent variables. Types of

The dependent variables in the cross-sectional models, $Y_{i j}^{\text {Camp,t=0 }}$ and $Y_{i j}^{P a r t y, t=0}$, depict the two forms of agreement within a dyad of respondent $i$ and discussant $j$ at time $t=0$ (pre-election interview). Accordingly, $Y_{i j}^{C a m p, t=1}$ and $Y_{i j}^{\text {Party,t=1 }}$ are the dependent variables in the panel models and represent agreement within a dyad of respondent $i$ and discussant $j$ at time $t=1$ (post-election interview). $\Phi$ is the cumulative density function of the standard normal distribution, the link function of the probit model. The matrices $D_{P} i j h$ and $D_{I i j k}$ contain the independent variables indicative of social pressure $(h=5)$ and information sharing $(k=4)$ within the dyad of respondent $i$ and discussant $j$. The matrices $C_{R i l}$ and $C_{D i j m}$ contain the control variables. The former includes $l=6$ individual characteristics of respondent $i$, the latter captures $m=1$ feature of the $j$ th discussant of respondent $i$ (the party supported by the discussant). The panel models include the lagged dependent variables, $Y_{i j}^{\text {Camp,t } t=0}$ or $Y_{i j}^{P a r t y, t=0}$, as additional control variables. The vectors $\beta_{h}, \gamma_{k}, \delta_{l}, \zeta_{m}$ and $\eta$ comprise the corresponding coefficients and $\alpha$ is the constant. AMEs derived from these models are compared in the third and essential step of the analysis. For both cross-sectional and panel analyses the AMEs pertaining to $D_{P} i j h$ are expected to be larger in models (1) than in (2), whereas the reverse is expected for $D_{I} i j k$.

${ }^{101}$ Pattie and Johnston 2002.

${ }^{102}$ Sinclair 2012, 12-3, 105-7, 151-3. 
relationships are included to indicate the role of social pressure, the frequency of political conversations and the clarity of communicated messages as well as the perceived political expertise and trustworthiness of discussants indicate the importance of information sharing.

Before looking at our findings in detail, it is important to note that our analysis confirms all premises from which we developed our hypotheses. Discussant influence at elections does indeed vary by the type of relationship, but also by the frequency of political conversations and the clarity of communicated messages as well as the perceived political expertise and trustworthiness of discussants. Hence, like previous studies we find evidence for both mechanisms of discussant influence. However, testing our hypotheses requires moving beyond these basic observations by inspecting the differences between the first and the second stage of the decision process.

Larger AME estimates for primary than for secondary relationships suggest that social pressure is stimulating voters to bring their electoral preferences in line with those of their discussants. In contrast, if information sharing is the operating mechanism of discussant influence, 'there should be no heterogeneous effects based on the intensity of personal relationships'. ${ }^{103}$ However, both the cross-sectional and panel analyses find significant differences of that kind. In most analyses, voters' preferences are much more likely to correspond to those of their spouses than to secondary relationships (which do not differ between themselves). Three out of four models also indicate a particularly influential role of relatives, although to a lesser degree than spouses. Friends differ from secondary relationships only in the cross-sectional model predicting preferences for a party of the same ideological camp, and the effect is weaker again than for relatives.

Importantly, according to Table 4 the likelihood for voters to converge in their choices to the parties preferred by their discussants instead of sticking with another, ideologically adjacent party is not affected by the nature of relationships, whereas movements towards

\footnotetext{
${ }^{103}$ Sinclair 2012, 10.
} 
parties from the same ideological camp appear responsive to relationships. Coming from panel models these observations are especially robust, and they are well in line with hypothesis H1. But to test this expectation properly we need to compare the patterns of relationships across the two stages of the decision process. If $\mathrm{H} 1$ is correct we should see significantly larger differences between primary and secondary relationships for the first stage than for the second stage. In other words, the difference between intimate and functional relationships with regard to voters' likelihood to conform to their discussants should be more sizable for the distinction between voting for a party of the same and not the opposing ideological direction than for the distinction between voting for the same party and favouring another party from the same camp.

For both spouses and relatives such a pattern is indeed registered by the crosssectional and in particular also the panel analysis. For friendships our finding is similarly clear-cut only in the cross-sectional model. While friends' influence appears considerably stronger than that of co-workers at the first stage of the decision process, no such difference is found for the second stage. Correspondingly, the difference between the two models is even larger for friends than for spouses and relatives. However, friendship does not appear to spur short-term change towards parties of the same ideological leaning more strongly than workplace ties. Overall, $\mathrm{H} 1$ is thus clearly confirmed for two of the three types of primary relationships distinguished in our analysis, but less unambiguously so for friendship. That our short-term panel analysis supports our expectation of stronger effects in the first step of decision-making for spouses and relatives is particularly remarkable since our theory assumes this step to be rather long-term in nature. Table 4 suggests that the mechanism of social pressure exerted within these relationships also works on the short run, although probably less massively than on the long run. 
Table 3: Moderators of discussant influence: cross-sectional models (probit estimates for dyads)

\begin{tabular}{|c|c|c|c|c|c|c|}
\hline & \multicolumn{2}{|c|}{ Same camp } & \multicolumn{2}{|c|}{$\begin{array}{l}\text { Same party } \\
\text { within camp }\end{array}$} & \multicolumn{2}{|c|}{$\begin{array}{l}\text { Difference } \\
\text { camp minus party }\end{array}$} \\
\hline & $\begin{array}{l}\text { Estimate } \\
\text { (Sig.) }\end{array}$ & AME & $\begin{array}{l}\text { Estimate } \\
\text { (Sig.) }\end{array}$ & AME & $\triangle \mathrm{AME}$ & $\begin{array}{l}\text { 95\%-Confidence } \\
\text { interval }\end{array}$ \\
\hline \multicolumn{7}{|l|}{$\begin{array}{l}\text { Type of relationship (ref. co- } \\
\text { worker): }\end{array}$} \\
\hline - Spouse/life partner & $0.53 * * *$ & $0.15 * * *$ & $0.38 * * *$ & $0.12 * * *$ & 0.03 & {$[0.02-0.04]$} \\
\hline - Relative & $0.30 * *$ & $0.09 * *$ & $0.21 *$ & $0.07 *$ & 0.02 & {$[0.01-0.03]$} \\
\hline - Friend & $0.20 *$ & $0.06^{*}$ & -0.01 & -0.00 & 0.06 & {$[0.05-0.08]$} \\
\hline - Neighbour & -0.32 & -0.10 & -0.03 & -0.01 & -0.09 & {$[-0.12--0.06]$} \\
\hline - Other & -0.03 & -0.01 & 0.01 & 0.00 & -0.01 & {$[-0.04-0.01]$} \\
\hline $\begin{array}{l}\text { Most frequent discussant } \\
(1=\text { yes, } 0=\text { no })\end{array}$ & -0.04 & -0.01 & $0.21 * * *$ & $0.07 * * *$ & -0.08 & {$[-0.08--0.07]$} \\
\hline $\begin{array}{l}\text { Discussant effective } \\
\text { communication (RL) }\end{array}$ & -0.01 & -0.00 & $-0.08 * * *$ & $-0.03 * * *$ & 0.02 & {$[0.02-0.02]$} \\
\hline $\begin{array}{l}\text { Discussant political expertise } \\
(0-3)\end{array}$ & $0.31 * * *$ & $0.09 * * *$ & $0.13 * *$ & $0.04 * *$ & 0.05 & {$[0.04-0.05]$} \\
\hline $\begin{array}{l}\text { Discussant political } \\
\text { trustworthiness }(0-3)\end{array}$ & $0.61 * * *$ & $0.17 * * *$ & $0.33^{* * *}$ & $0.10 * * *$ & 0.07 & {$[0.06-0.08]$} \\
\hline
\end{tabular}




\begin{tabular}{|c|c|c|c|c|c|c|}
\hline $\begin{array}{l}\text { PId-vote correspondence } \\
(1=\text { yes, } 0=\text { no/no PId/undecided })\end{array}$ & $0.77 * * *$ & $0.23 * * *$ & $0.99 * * *$ & $0.34 * * *$ & -0.11 & {$[-0.12--0.10]$} \\
\hline $\begin{array}{l}\text { Evaluation of grand coalition ( }-5 \\
-+5)\end{array}$ & $-0.02 *$ & $-0.01 *$ & 0.02 & 0.01 & -0.01 & {$[-0.01--0.01]$} \\
\hline $\begin{array}{l}\text { Interest in election outcome (0- } \\
\text { 4) }\end{array}$ & 0.05 & 0.01 & 0.05 & 0.02 & 0.00 & {$[-0.01-0.00]$} \\
\hline \multicolumn{7}{|l|}{$\begin{array}{l}\text { Vote intention of discussant } \\
\text { (ref. CDU/CSU): }\end{array}$} \\
\hline - SPD & 0.03 & 0.01 & $-0.34 * * *$ & $-0.11 * * *$ & 0.11 & {$[0.11-0.12]$} \\
\hline - FDP & -0.01 & -0.00 & $-0.34 * *$ & $-0.11 * *$ & 0.11 & {$[0.08-0.13]$} \\
\hline - Greens & $0.21 *$ & $0.06^{*}$ & $-0.35 * * *$ & $-0.11 * * *$ & 0.17 & {$[0.15-0.18]$} \\
\hline - Left & $0.25^{*}$ & $0.07 *$ & $-0.26^{*}$ & $-0.08^{*}$ & 0.15 & {$[0.13-0.16]$} \\
\hline Age (in years) & $0.01 * * *$ & $0.00 * * *$ & 0.00 & 0.00 & 0.00 & {$[0.00-0.00]$} \\
\hline Sex $(1=$ male, $0=$ female $)$ & $0.17 * *$ & $0.05 * *$ & -0.06 & -0.02 & 0.07 & {$[0.06-0.08]$} \\
\hline $\begin{array}{l}\text { Education }(1=\text { secondary } \\
\text { compltd., } 0=\text { lower })\end{array}$ & 0.03 & 0.01 & -0.06 & -0.02 & 0.03 & {$[0.02-0.03]$} \\
\hline Constant & $-2.15 * * *$ & & $-1.41 * * *$ & & & \\
\hline McKelvey \& Zavoina $\mathrm{R}^{2}$ & 0.38 & & 0.34 & & & \\
\hline $\mathrm{N}$ & 2,702 & & 2,116 & & & \\
\hline
\end{tabular}


confidence interval indicates whether this difference significantly differs from zero. 
Table 4: Moderators of discussant influence: panel models (probit estimates for dyads)

\begin{tabular}{|c|c|c|c|c|c|c|}
\hline & \multicolumn{2}{|c|}{ Same camp } & \multicolumn{2}{|c|}{$\begin{array}{l}\text { Same party } \\
\text { within camp }\end{array}$} & \multicolumn{2}{|c|}{$\begin{array}{c}\text { Difference } \\
\text { camp minus party }\end{array}$} \\
\hline & $\begin{array}{l}\text { Estimate } \\
\text { (Sig.) }\end{array}$ & AME & $\begin{array}{l}\text { Estimate } \\
\text { (Sig.) }\end{array}$ & AME & $\triangle \mathrm{AME}$ & $\begin{array}{l}\text { 95\%-Confidence } \\
\text { interval }\end{array}$ \\
\hline \multicolumn{7}{|l|}{ Type of relationship (ref. co-worker): } \\
\hline - Spouse/life partner & $0.64 * * *$ & $0.08 * * *$ & 0.24 & 0.05 & 0.03 & {$[0.00-0.06]$} \\
\hline - Relative & $0.32 *$ & $0.04 *$ & 0.11 & 0.03 & 0.02 & {$[-0.01-0.05]$} \\
\hline - Friend & 0.16 & 0.02 & 0.10 & 0.02 & 0.00 & {$[-0.03-0.03]$} \\
\hline - Neighbour & 0.37 & 0.05 & 0.18 & 0.04 & 0.01 & {$[-0.04-0.07]$} \\
\hline - Other & 0.10 & 0.01 & 0.15 & 0.03 & -0.02 & {$[-0.09-0.05]$} \\
\hline Most frequent discussant $(1=$ yes, $0=$ no $)$ & -0.04 & -0.01 & $0.18^{*}$ & $0.04 *$ & -0.04 & {$[-0.06--0.03]$} \\
\hline $\begin{array}{l}\text { Discussant effective communication } \\
\text { (RL) }\end{array}$ & 0.02 & 0.00 & -0.02 & -0.00 & 0.01 & {$[0.00-0.01]$} \\
\hline Discussant political expertise (0-3) & $0.24 * *$ & $0.03 * *$ & 0.05 & 0.01 & 0.02 & {$[0.01-0.03]$} \\
\hline $\begin{array}{l}\text { Discussant political trustworthiness (0- } \\
\text { 3) }\end{array}$ & $0.53 * * *$ & $0.07 * * *$ & 0.06 & 0.01 & 0.05 & {$[0.04-0.07]$} \\
\hline $\begin{array}{l}\text { Lag variable }(1=\text { discussant and voter } \\
\text { same camp/party in pre-election wave, } \\
0=\text { not same camp/party })\end{array}$ & $2.43 * * *$ & $0.59 * * *$ & $1.83 * * *$ & $0.57 * * *$ & 0.02 & {$[-0.01-0.04]$} \\
\hline
\end{tabular}


PId-vote correspondence (1=yes, $0=$ no/no PId/undecided)

Evaluation of grand coalition $(-5-+5)$

Interest in election outcome (0-4)

Vote intention of discussant (ref.

$\mathrm{CDU} / \mathrm{CSU})$ :

- SPD

- FDP

- Greens

- Left

Age (in years)

Sex $(1=$ male, $0=$ female $)$

Education ( $1=$ secondary compltd., $0=$

lower)

Constant

McKelvey \& Zavoina $\mathrm{R}^{2}$

$\mathrm{N}$

Note: $* \mathrm{p}<.05 ; * * \mathrm{p}<.01 ; * * * \mathrm{p}<.001$ (cluster-robust standard errors). The average marginal effect (AME) for dummy variables indicates the discrete change from the base level. $\triangle \mathrm{AME}$ is the difference in AME between the camp and the party model; the $95 \%$-confidence interval indicates whether this difference significantly differs from zero.

$0.33 * * * \quad 0.04 * * \quad 0.46 * * * \quad 0.11 * * * \quad-0.06 \quad[-0.08--0.05]$

$\begin{array}{llllll}-0.01 & -0.00 & 0.03 * & 0.01 * & -0.01 & {[-0.01--0.01]}\end{array}$

$\begin{array}{llllll}-0.01 & -0.00 & 0.08 & 0.02 & -0.02 & {[-0.03--0.01]}\end{array}$

0.02

0.27

0.00

$-0.04$

$-0.01$

$0.01 \quad[-0.01-0.04]$

0.12

0.03

0.11

0.02

$0.01 \quad[-0.03-0.05]$

$0.84 * * *$

0.02

$-0.14$

$-0.03$

$0.05 \quad[0.02-0.07]$

$-0.00$

0.06

$0.04 \quad[0.02-0.06]$

$-0.22 *$

$-0.03$

$-0.00$

$-0.00$

$0.00 \quad[0.00-0.00]$

$0.05 \quad[0.03-0.07]$

0.01

0.00

$-0.02$

$-0.00$

$0.01 \quad[-0.01-0.02]$

$-1.91 * * *$

0.69

0.51

1,948

1,427 
The other independent variables in the models concern aspects of information sharing between discussants and voters. These effects should be stronger for the second stage of the decision process, when voters make up their minds about which party to choose from those contained in their consideration sets. As Tables 3 and 4 show, the likelihood of voters adopting the preferences of their discussants appears indeed higher when politics is discussed more often, but only for voters' decision between the same party as supported by their discussant and other parties from the same ideological camp. This suggests that information sharing and concomitant learning on the part of voters play not only a less important role, but are in fact irrelevant at the first stage of decision making which is well in line with $\mathrm{H} 2 \mathrm{a}$. This result is clearly confirmed by the panel analysis and thus particularly robust.

The expectation that effective communication on the part of discussants increases the likelihood of adopting their electoral preferences at the second stage of decision making is confirmed by the cross-sectional analysis. That the clarity of communication appears as an important facilitator of electoral influence at that stage, but not at the previous one, when consideration sets are demarcated, is in accordance with $\mathrm{H} 2 \mathrm{~b}$. It is another indication that in multi-party systems discussant influence via information sharing is more characteristic of the second than the first stage of electoral decision making. However, this evidence is less robust as it is not showing up in the panel analysis.

Hypotheses $\mathrm{H} 2 \mathrm{c}$ and $\mathrm{H} 2 \mathrm{~d}$ expect similar patterns with regard to discussants' perceived political expertise and trustworthiness. In line with extant research Tables 3 and 4 show that discussants endowed with substantial political knowledge exert considerably more influence than those with lower expertise. The degree to which discussants are deemed politically trustworthy appears even more important as a condition for electoral influence. However, comparing models we see that the pattern is reverse to the one expected by our hypotheses which are thus disconfirmed. In both the cross-sectional and the panel models the effects of discussants' political expertise and trustworthiness are stronger for the first than for the second 
stage of decision making. One possible reason for this unexpected outcome is that these two indicators might be less clearly related to information sharing as mechanism of discussant influence than we assumed. To test for this possibility we ran additional models (tables not shown) without these two indicators which led to a considerable strengthening of the effects connected to types of relationships. While this cannot fully explain our unexpected findings it suggests that as moderators of discussant influence these variables are not sufficiently clearly indicative of processes of information transfer. They seem to confound the two mechanisms of discussant influence. Their operational utility for differentiating these mechanisms thus appears questionable.

In sum, when modelling German voters' electoral decision making in two stages, one delimiting a range of electable parties that are constrained to the same ideological direction, the other determining which party from this restricted set is ultimately chosen, discussant influence appears relevant at both stages. However, different mechanisms of influence seem to characterize the two steps. Our evidence on these mechanisms is mostly, though not unequivocally in line with our hypotheses. The expectation that social pressure is more important at the first stage is clearly confirmed, especially for spouses and relatives. Support for the proposition that information sharing is more important at the second stage is not quite as unambiguous. With regard to two of the relationships that speak for information sharing as mechanism of influence - concerning the intensity and clarity of the discussants' political communication - the expected patterns emerged. However, possibly at least in part due to an ambiguous quality of these two predictors as indicators for distinguishing the two mechanisms of discussant influence our findings concerning discussants' political expertise and trustworthiness are not in line with our expectations.

\section{$\underline{\text { Conclusion }}$}


Extant research into discussant influence at elections has in two ways been dominated by studies from the United States. For one, the large majority of existing analyses has focused at candidate elections in the American two-party system. More importantly, studies of elections in other countries have with few exceptions adopted this research as model and conceptualized discussant influence in the same way. The specific institutional settings of these contexts have rarely been taken into account. With regard to West European democracies it is therefore unclear how the specific conditions of cleavage-based, ideologically structured multi-party systems with their typical patterns of opposition, but also affinity between parties moderate discussant influence. Another shortcoming of the existing literature concerns the relationship between different mechanisms of discussant influence. Both cognitive and affective mechanisms appear important, but when and under which conditions is not clear.

We have sought to address both deficiencies by developing a two-stage theory of discussant influence in West European multi-party systems. In essence it is derived from two theoretical building blocks. The first is the idea that in multi-party systems voters decide in a step-wise fashion, first narrowing down the range of alternatives to a set of parties from one side of the ideological spectrum, and then choosing a party out of this restricted set. ${ }^{104}$ This construal of electoral decision making is linked to the two dominant views on mechanisms of discussant influence at elections: that voters comply with social pressure exerted by significant others, and that they learn from information provided by persons with whom they interact. ${ }^{105}$ Our theory of stepwise discussant influence maintains that social pressure and ensuing conformity are especially important at the first stage of the electoral decision process when they lead voters to eliminate all parties from their considerations sets that do not belong

\footnotetext{
${ }^{104}$ Oscarsson, Gilljam and Granberg 1997; Pieters and Verplanken 1995; Plischke and Bergmann 2012; Steenbergen and Hangartner 2008; Wilson 2008.

${ }^{105}$ Ikeda 2010; Leighley 1990; Sinclair 2012.
} 
to the same ideological camp as the party supported by their discussants. It further contends that at the second stage, when a choice has to be made out of this restricted set of ideologically coherent parties, alternatives need to be weighed up more carefully and systematically, so that useful information provided by discussants becomes more important as basis for their influence at that stage. We construe the first stage as a process which is rather long-term, potentially spanning entire electoral cycles and driven by continuous interaction of voters with members of their social networks, whereas the latter is rather short-term and primarily fueled by voters' political conversations during campaigns.

Using the German federal election 2009 as an example we subjected this theory to an empirical test. To develop a test criterion for distinguishing between the two mechanisms of discussant influence we adopted a logic proposed by Sinclair ${ }^{106}$ and referred to implied patterns of moderating factors that can be considered typical for each of them. Our findings were mostly in line with the expectations derived from our two-stage theory.

Primary relationships appeared as important facilitators of discussant influence especially at the stage when consideration sets are formed by excluding parties from the 'wrong' ideological camp. This suggests that social pressure is more important at the first stage of electoral decision making than at the second. In multi-party systems social pressure is of particular importance when voters narrow down the range of electable alternatives to ones that are ideologically acceptable to discussants. Importantly, these findings emerged even in our short-term panel analysis although our theory assumes these processes to be predominantly long-term in nature. Since we applied a fine-grained lens at differences between relationships we were additionally able to show that the various types of primary relationships are not equivalent. Spouses appeared particularly important, followed by relatives, whereas findings were somewhat ambiguous for friends. At least on the short run, social pressure among friends does not seem to spur convergence to parties from the same

\footnotetext{
${ }^{106}$ Sinclair 2012, 12-3.
} 
ideological camp. Perhaps friendship as an archetypical chosen relationship is more strongly affected by selection bias. In any case, simply subsuming these three types of relationships to the global category of 'strong ties' would neglect important differences with regard to discussant influence. ${ }^{107}$

Regarding influence via social information flows, on the other hand, strong moderating effects were expected for factors directly related to social communication. Frequent political talks ${ }^{108}$ and the clarity of discussants' political communications ${ }^{109}$ indeed appeared to facilitate discussant influence at the stage of party choice, but not with regard to the formation of consideration sets. Voters appeared also particularly open to be influenced by discussants deemed particularly knowledgeable and trustworthy. ${ }^{110}$ But here the observed patterns were contrary to our expectations, since they were more marked for the first than for the final stage of decision making. However, in part this may be due to ambiguities in the discriminative quality of these indicators with regard to the two mechanisms of discussant influence. Overall, our results provide strong, though not fully equivocal support for the assumption that information sharing is particularly important as mechanism of discussant influence when it comes to deciding which party to support at the ballots out of those contained in voters' pre-filtered consideration sets.

Clearly, our study is not without limitations. Most notably, its evidence could not be derived from direct observation of the two processes of social influence, but from their implications. Our measures indicate qualities of relationships, interactions and communications between respondents and discussants, but it would be welcome to be able to

\footnotetext{
${ }^{107}$ Cf. Eveland, Morey and Hutchens 2011.

${ }^{108}$ Kenny 1994, 1998; Knoke 1990.

${ }^{109}$ Huckfeldt, Johnson and Sprague 2004, 68-97.

${ }^{110}$ Downs 1965, 230-3; Lupia and McCubbins 1998; Huckfeldt 2001; Huckfeldt and Sprague 1995; Levine 2005.
} 
register also the specific content conveyed during political conversations. However, such data are difficult to come by, and large-scale surveys may in fact be too crude for that purpose. In order to get more precise readings of what is actually going on between citizens when they influence one another it seems more promising to combine surveys with qualitative methods, such as focus groups ${ }^{111}$ or participant observation ${ }^{112}$, and with experimental evidence ${ }^{113}$. More direct evidence would also be welcome with regard to our contention that voters decide in stages with different temporal logics. Our results are suggestive, but in order to observe how voters' decision processes actually evolve over time data would be necessary that combine short-term with long-term panel waves. In addition, more extensive measures for voters' egocentric networks would be welcome, encompassing a larger number of discussants with more personal and relational attributes, ideally enriched with snowball surveys of discussants. ${ }^{114}$

Arguably, the most serious limitation of our study is its restriction to one country. The scope of our theory extends to parliamentary elections in all multi-party systems where parties are arrayed on the left-right continuum as single most important dimension of organizing political conflict. As soon as several electorally important parties can with some constancy be located on one of the two sides of the ideological spectrum, and provided left-right identities are a meaningful element of citizens' political personalities the sequential social influence processes outlined by our theory should be observable at elections. This clearly pertains to most West European democracies where such systems grew out of socio-political cleavages dating back several centuries. ${ }^{115}$ Whether other attributes of party systems additionally

\footnotetext{
${ }^{111}$ E.g., Klofstad 2011.

${ }^{112}$ E.g., Walsh 2004.

${ }^{113}$ E.g., Parker, Parker and McCann 2008.

${ }^{114}$ Huckfeldt, Johnson and Sprague 2004; Huckfeldt and Sprague 1995.

${ }^{115}$ Cf., e.g., Bartolini and Mair 1990; Knutsen 1998; Klingemann 2005; Dalton 2008.
} 
moderate these processes ${ }^{116}$, and whether similar processes can also be expected in multiparty systems of other parts of the world is open to further theorizing and empirical inquiry.

\section{$\underline{\text { References }}$}

Abrams, Samuel, Torben Iversen and David Soskice. 2011. Informal Social Networks and Rational Voting. British Journal of Political Science 41:229-257.

Alford, John R., Peter K. Hatemi, John R. Hibbing, Nicholas G. Martin and Lindon J. Eaves. 2011. The Politics of Mate Choice. Journal of Politics 73: 362-379.

Baldassarri, Delia. 2013. The Simple Art of Voting. The Cognitive Shortcuts of Italian Voters. Oxford: Oxford University Press.

Bartolini, Stefano and Peter Mair. 1990. Identity, Competition and Electoral Availability: The Stabilisation of European Electorates, 1885-1985. Cambridge: Cambridge Univesity Press.

Baumeister, Roy F., and Mark R. Leary. 1995. The Need to Belong: Desire for Interpersonal Attachments as a Fundamental Human Motivation. Psychological Bulletin 117(3): 497-529.

Bello, Jason and Meredith Rolfe. 2014. Is Influence Mightier Than Selection? Forging Agreement in Political Discussion Networks During a Campaign. Social Networks 36: 134-146.

Berelson, Bernard R., Paul F. Lazarsfeld and William N. McPhee. 1954. Voting. A Study of Opinion Formation in a Presidential Campaign. Chicago: University of Chicago Press.

\footnotetext{
${ }^{116}$ For instance, party families within the same ideological camps, varying party sizes, experiences of electoral proto-coalitions and coalition governments or the ideological polarization of party systems might additionally structure the 'social logic' of voters' choices within multi-party systems.
} 
Brandt, Patrick T. and Christiana J. Schneider. 2007. So the Reviewer Told You to Use a Selection Model? Selection Models and the Study of International Relations. Unpublished manuscript. Available from http://polisci2.ucsd.edu/cjschneider/working_papers/pdf/Selection-W041.pdf, accessed 25 March 2013.

Bytzek, Evelin and Sigrid Roßteutscher. 2011. Holpriger Start einer Wunschehe? Die Regierungsbildung der schwarz-gelben Koalition. Pp. 265-80 in Zwischen Langeweile und Extremen: Die Bundestagswahl 2009, edited by Hans Rattinger, Sigrid Roßteutscher, Rüdiger Schmitt-Beck and Bernhard Weßels. Baden-Baden: Nomos.

Campus, Donatella, Gianfranco Pasquino and Cristian Vaccari. 2008. Social Networks, Political Discussion, and Voting in Italy: A Study of the 2006 Election. Political Communication 25: 423-44.

Coffé, Hilde, and Ariana Need. 2010. Similarity in husbands and wives party family preference in the Netherlands. Electoral Studies 29: 259-268.

Dalton, Russell J. 2008. The Quantity and Quality of Party Systems. Comparative Political Studies 41(7): 899-920.

Dalton, Russell J., David M. Farrell and Ian McAllister. 2011. Political Parties and Democratic Linkage: How Parties Organize Democracy. Oxford: Oxford University Press.

de Vries, Catherine E. and Martin Rosema. 2008. Taking Voters' Consideration Set into Consideration: Modelling Electoral Choice in Two Stages. Paper presented at the 5th ECPR General Conference, Potsdam, Germany.

Downs, Anthony. 1965. An Economic Theory of Democracy. Boston: Addison Wesley.

Eveland, William P. Jr. and Myiah Hutchens Hively. 2009. Political Discussion Frequency, Network Size, and "Heterogeneity" of Discussion as Predictors of Political Knowledge and Participation. Journal of Communication 59(2): 205-24. 
Eveland, William P., Alyssa C. Morey and Myiah J. Hutchens. 2011. Beyond Deliberation: New Directions for the Study of Informal Political Conversation from a Communication Perspective. Journal of Communication 61(6): 1082-103.

Fleury, Christopher J. and Michael S. Lewis-Beck. 1993. Anchoring the French Voter: Ideology Versus Party. Journal of Politics 55(4): 1100-9.

Fowler, James H., Michael T. Heaney, David W. Nickerson, John F. Padgett and Betsy Sinclair. 2011. Causality in Political Networks. American Politics Research 39: 437480.

Gertzen, Heiner. 1992. Component Processes of Phased Decision Strategies. Acta Psychologica 80(1-3): 229-46.

Hanmer, Michael J. and Kerem Ozan Kalkan. 2013. Behind the Curve: Clarifying the Best Approach to Calculating Predicted Probabilities and Marginal Effects from Limited Dependent Variable Models. American Journal of Political Science 57(1): 263-77.

Hopmann, David Nicolas. 2012. The Consequences of Political Disagreement in Interpersonal Communication: New Insights from a Comparative Perspective. European Journal of Political Research 51(2): 265-87.

Huckfeldt, Robert. 2007. Information, Persuasion, and Political Communication Networks. Pp. 100-22 in The Oxford Handbook of Political Behavior, edited by Russell J. Dalton and Hans-Dieter Klingemann. Oxford: Oxford University Press.

Huckfeldt, Robert. 2001. The Social Communication of Political Expertise. American Journal of Political Science 45(2): 425-38.

Huckfeldt, Robert, Paul Allen Beck, Russell J. Dalton and Jeffrey Levine. 1995. Political Environments, Cohesive Social Groups, and the Communication of Public Opinion. American Journal of Political Science 39(4): 1025-54. 
Huckfeldt, Robert, Paul Allen Beck, Russell J. Dalton, Jeffrey Levine and William Morgan. 1998. Ambiguity, Distorted Messages, and Nested Environmental Effects on Political Communication. Journal of Politics 60: 996-1030.

Huckfeldt, Robert, Ken'ichi Ikeda and Franz Urban Pappi. 2005. Patterns of Disagreement in Democratic Politics: Comparing Germany, Japan, and the United States. American Journal of Political Science 49(3): 497-514.

Huckfeldt, Robert, Paul Johnson and John Sprague. 2004. Political Disagreement. The Survival of Diverse Opinions within Communication Networks. Cambridge: Cambridge University Press.

Huckfeldt, Robert and John Sprague. 1991. Discussant Effects on Vote Choice: Intimacy, Structure, and Interdependence. Journal of Politics 53(1): 122-58.

Huckfeldt, Robert and John Sprague. 1995. Citizens, Politics, and Social Communication. Information and Influence in an Election Campaign. Cambridge/New York: Cambridge University Press.

Huckfeldt, Robert, John Sprague and Jeffrey Levine. 2000. The dynamics of collective deliberation in the 1996 election: Campaign effects on accessibility, certainty, and accuracy. American Political Science Review 94: 641-651.

Ikeda, Ken'ichi. 2010. Social Networks, Voting and Campaign Participation in Japan. The Interpersonal Political Environment and the Autonomous Dimension of Social Networks. Pp. 162-82 in Political Discussion in Modern Democracies. A Comparative Perspective, edited by Michael R. Wolf, Laura Morales and Ken'ichi Ikeda. London/New York: Routledge.

Ikeda, Ken'ichi, and Sean Richey. 2009. The Impact of Diversity in Informal Social Networks on Tolerance in Japan. British Journal of Political Science 39(3): 655-68.

Johnston, Ron, and Charles Pattie. 2006. Putting Voters in Their Place. Geography and Elections in Great Britain. Oxford: Oxford University Press. 
Karlsen, Rune, and Bernt Aardal. 2012. Political Values, Party Set, and Issue Ownership: How Stable and Dynamic Factors Affect Vote Choice in Multiparty Systems. Paper presented at the 2nd EPSA Annual Conference, Berlin, Germany, 21 - 23 June.

Kenny, Christopher B. 1998. The Behavioral Consequences of Political Discussion: Another Look at Discussant Effects on Vote Choice. Journal of Politics 60(1): 231-44.

Kenny, Christopher B. 1994. The Microenvironment of Attitude Change. Journal of Politics 56: 715-28.

Klingemann, Hans-Dieter. 2005. 2005. Political Parties and Party Systems. Pp. 22-63 in The European voter. A comparative study of modern democracies, edited by Jacques Thomassen. Oxford: Oxford University Press.

Klofstad, Casey A. 2011. Civic Talk. Peers Politics, and the Future of Democracy. Philadelphia: Temple University Press.

Klofstad, Casey A., Anand Sokhey and Scott D. McClurg. 2013. Disagreeing About Disagreement: How Conflict in Social Networks Affects Political Behavior. American Journal of Political Science 57(1): 120-34.

Klofstad, Casey A., Rose McDermott and Peter K. Hatemi. 2012. Do bedroom eyes wear political glasses? The role politics in human mate attraction. Evolution and Human Behavior 33: 100-8.

Klofstad, Casey A., Rose McDermott and Peter K. Hatemi. 2013. The Dating Preferences of Liberals and Conservatives. Political Behavior 35: 519-38.

Knoke, David. 1990. Networks of Political Action: Toward Theory Construction. Social Forces 68(4): 1041-63.

Knutsen, Oddbjørn. 1995. Value Orientations, Political Conflicts and Left-Right Identification: A Comparative Study. European Journal of Political Research 28(1): 63-93. 
Knutsen, Oddbjørn. 1998. Expert Judgements of the Left-Right Location of Political Parties: A Comparative Longitudinal Study. West European Politics 21(2): 63-94.

Koßmann, Ingo. 1995. Meinungsbildungsprozesse in egozentrierten Netzwerken. Frankfurt: Lang.

Lazarsfeld, Paul F., Bernard Berelson and Hazel Gaudet. 1968. The People's Choice. How the Voter Makes up His Mind in a Presidential Campaign. 3rd edition. New York/London: Columbia University Press.

Lazer, David, Brian Rubineau, Carol Chetkovich, Nancy Katz and Michael Neblo. 2010. The Coevolution of Networks and Political Attitudes. Political Communication 27: 24874.

Leighley, Jan E. 1990. Social Interaction and Contextual Influence on Political Participation. American Politics Quarterly 18: 459-75.

Levine, Jeffrey. 2005. Choosing Alone? The Social Network Basis of Modern Political Choice. Pp. 132-51 in The Social Logic of Politics. Personal Networks as Contexts for Political Behavior, edited by Alan Zuckerman. Philadelphia: Temple University Press.

Little, Roderick J. A. 1985. A Note About Models for Selectivity Bias. Econometrica 53(6): 1469-74.

Little, Roderick J. A. and Donald B. Rubin. 1987. Statistical Analysis with Missing Data. New York: Wiley.

Lup, Oana. 2010. The Role of Political Discussion in Developing Democracies. Evidence from Hungary. Pp. 183-200 in Political Discussion in Modern Democracies. A Comparative Perspective, edited by Michael R. Wolf, Laura Morales and Ken'ichi Ikeda. London/New York: Routledge.

Lupia, Arthur and Mathew D. McCubbins. 1998. The Democratic Dilemma. Can Citizens Learn What They Need to Know? Cambridge/New York: Cambridge University Press. 
MacKuen, Michael and Courtney Brown. 1987. Political Context and Attitude Change. American Political Science Review 81(2): 471-90.

Magalhães, Pedro C. 2007. Voting and Intermediation: Informational Biases and Electoral Choices in Comparative Perspective. Pp. 208-54 in Democracy, Intermediation, and Voting on Four Continents, edited by Richard Gunther, Jose Ramon Montero and Hans-Jürgen Puhle. Oxford: Oxford University Press.

Marsden, Peter V. 1987. Core Discussion Networks of Americans. American Sociological Review 52: 122-31.

Martin, Lanny W. and Randolph T. Stevenson. 2001. Government Formation in Parliamentary Democracies. American Journal of Political Science 45(1): 33-50.

Mayerl, Jochen, and Dieter Urban. 2008. Antwortreaktionszeiten in Survey-Analysen: Messung, Auswertung und Anwendungen. Wiesbaden: VS Verlag für Sozialwissenschaften.

McClosky, Herbert and Harold E. Dahlgren. 1959. Primary Group Influence on Party Loyalty. American Political Science Review 53: 757-76.

McClurg, Scott. 2011. Porous Networks and Overlapping Contexts. Methodological Challenges in the Study of Social Communication and Political Behavior. Pp. 346-64 in The Sourcebook for Political Communication Reserach. Methods, Measures, and Analytical Techniques, edited by Erik P. Bucy and R. Lance Holbert. New York/London: Routledge.

McPhee, William N., Mark Ferguson and Robert B. Smith. 1963. A Theory of Informal Social Influence. Glencoe/London: Free Press/Collier Macmillan.

McPherson, Miller, Lynn Smith-Lovin and James M. Cook. 2001. Birds of a Feather: Homophily in Social Networks. Annual Review of Sociology 27: 415-444. 
Meffert, Michael F., Sascha Huber, Thomas Gschwend and Franz Urban Pappi. 2011. More Than Wishful Thinking: Causes and Consequences of Voters' Electoral Expectations About Parties and Coalitions. Electoral Studies 30(4): 804-15.

Mood, Carina. 2010. Logistic Regression: Why We Cannot Do What We Think We Can Do, and What We Can Do About It. European Sociological Review 26(1): 67-82.

Mutz, Diana, and Jeffery Mondak. 2006. The Workplace as a Context for Cross-Cutting Political Discourse. Journal of Politics 68: 140-155.

Neundorf, Anja. 2012. Die Links-Rechts-Dimension auf dem Prüfstand: Ideologische Einstellungen und Wahlverhalten im vereinten Deutschland 1990 bis 2008. Pp. 227-51 in Wählen in Deutschland. PVS special issue 45, edited by Rüdiger Schmitt-Beck. Baden-Baden: Nomos.

Niedermayer, Oskar. 2006. Das Parteiensystem Deutschlands. Pp. 109-33 in Die Parteiensysteme Westeuropas, edited by Oskar Niedermayer, Richard Stöss and Melanie Haas. Wiesbaden: VS Verlag für Sozialwissenschaften.

Oscarsson, Henrik, Mikael Gilljam and Donald Granberg. 1997. The Concept of Party Set. Paper presented at the Annual Meeting of the Swedish Political Science Association, Uppsala, Sweden, 5 - 7 October.

Paap, Richard, Erjen van Nierop, Harald J. van Heerde, Michel Wedel, Philip Hans Franses and Karel Jan Alsem. 2005. Consideration Sets, Intentions and the Inclusion of "Don't Know" in a Two-Stage Model for Voter Choice. International Journal of Forecasting 21(1): 53-71.

Pappi, Franz Urban, and Gunter Wolf. 1984. Wahrnehmung und Realität sozialer Netzwerke. Zuverlässigkeit und Gültigkeit der Angaben über beste Freunde im Interview. Pp. 281300 in Soziale Realität im Interview, edited by Heiner Meulemann and Karl-Heinz Reuband, Frankfurt/New York: Campus. 
Parker, Suzanne L., Glenn R. Parker, und James A. McCann. 2008. Opinion Taking within Friendship Networks. American Journal of Political Science 52: 412-420.

Partheymüller, Julia, and Rüdiger Schmitt-Beck. 2012. A 'Social Logic' of Demobilization:

The Influence of Political Discussants on Electoral Participation at the 2009 German Federal Election. Journal of Elections, Public Opinion \& Parties 22(4): 457-478.

Pattie, Charles and Ron Johnston. 2002. Political Talk and Voting: Does It Matter to Whom One Talks? Environment and Planning 34: 1113-35.

Pattie, Charles and Ron Johnston. 2001. Talk as a Political Context: Conversation and Electoral Change in British Elections: 1992-1997. Electoral Studies 20: 17-40. Pattie, Charles and Ron Johnston. 2000. "People Who Talk Together Vote Together": An Exploration of Contextual Effects in Great Britain. Annals of the Association of American Geographers 90: 41-66.

Pieters, Rik G. M. and Bas Verplanken. 1995. Intention-Behaviour Consistency: Effects of Consideration Set Size, Involvement and Need for Cognition. European Journal of Social Psychology 25(5): 531-43.

Plischke, Thomas. 2014. Wann Wähler entscheiden. Abläufe von Entscheidungsprozesse $n$ und der Zeitpunkt der Wahlentscheidung. Baden-Baden: Nomos.

Plischke, Thomas and Michael Bergmann. 2012. Entscheidungsprozesse von Spätentscheidern bei der Bundestagswahl. Pp. 489-513 in Wählen in Deutschland. PVS special issue 45, edited by Rüdiger Schmitt-Beck. Baden-Baden: Nomos.

Rabinowitz, George and Stuart Elaine Macdonald. 1989. A Directional Theory of Issue Voting. American Political Science Review 83(1): 93-121.

Richardson, Bradley and Paul Allen Beck. 2007. The Flow of Political Information: Personal Discussants, the Media, and Partisans. Pp. 183-207 in Democracy, Intermediation, and Voting on Four Continents, edited by Richard Gunther, José Ramón Montero and Hans-Jürgen Puhle. Oxford: Oxford University Press. 
Richey, Sean. 2008. The Autoregressive Influence of Social Network Political Knowledge on Voting Behavior. British Journal of Political Science 38: 527-42.

Roberts, John H. and James M. Lattin. 1991. Development and Testing of a Model of Consideration Set Composition. Journal of Marketing Research 28(4): 429-40.

Roßteutscher, Sigrid and Philipp Scherer. 2011. Ideologie und Wertorientierungen. Pp. 26580 in Zwischen Langeweile und Extremen. Die Bundestagswahl 2009, edited by Hans Rattinger, Sigrid Roßteutscher, Rüdiger Schmitt-Beck and Bernhard Weßels. BadenBaden: Nomos.

Schickler, Eric, and Donald Green. 1997. The Stability of Party Identification in Western Democracies: Results from Eight Panel Surveys. Comparative Political Studies 30(4): 450-483.

Schmitt-Beck, Rüdiger. 2000. Politische Kommunikation und Wählerverhalten. Ein Internationaler Vergleich. Wiesbaden: VS Verlag.

Schmitt-Beck, Rüdiger. 2004. Political Communication Effects: The Impact of Mass Media and Personal Conversations on Voting. Pp. 293-322 in Comparing Political Communication. Theories, Cases, and Challenges, edited by Frank Esser. New York/London: Routledge.

Shalizi, Cosma Rohilla, and Andrew C. Thomas. 2011. Homophily and Contagion Are Generically Confounded in Observational Social Network Studies. Sociological Methods \& Research 40(2): 211-39.

Sherif, Muzafer, and Carl I. Hovland. 1961. Social Judgment. Assimilation and Contrast Effects in Communication and Attitude Change. New Haven: Yale University Press.

Shikano, Susumu. 2003. Construction of Choice Sets and Its Influence on Voting Decision: Application of the Probabilistic Choice Set Model for Voter Choice under Two-Ballot System in Germany and Japan. Paper presented at the ECPR joint sessions of workshops, Edinburgh, 28 March - 2 April. 
Shively, W. Phillips. 1972. Party Identification, Party Choice, and Voting Stability: The Weimar Case. American Political Science Review 66: 1203-25.

Shocker, Allan D., Moshe Ben-Akiva, Bruno Boccara and Prakash Nedungadi. 1991. Consideration Set Influences on Consumer Decision-Making and Choice: Issues, Models, and Suggestions. Marketing letters 2(3): 181-97.

Sinclair, Betsy. 2012. The Social Citizen. Peer Networks and Political Behavior. Chicago/London: University of Chicago Press.

Sniderman, Paul M., Richard A. Brody and Philip E. Tetlock. 1991. Reasoning and Choice. Cambridge/Mass.: Cambridge University Press.

Steenbergen, Marco R., and Dominik Hangartner. 2008. Political Choice Sets in Multi-Party Elections. Paper presented at the Workshop "The Politics of Change", Amsterdam, The Netherlands, 13 - 14 June.

Thomassen, Jacques (ed.). 2005. The European voter. A Comparative Study of Modern Democracies. Oxford: Oxford University Press.

van der Eijk, Cees, and Mark N. Franklin. 2009. Elections and Voters. Basingstoke, New York, NY: Palgrave Macmillan.

van der Eijk, Cees, and Broer Niemöller. 1983. Electoral Change in the Netherlands. Amsterdam: CT Press.

Walsh, Katherine Cramer. 2004. Talking about Politics: Informal Groups and Social Identity in American Life. Chicago: University of Chicago Press.

Weisberg, Herbert F. 1993. Political Partisanship. Pp. 681-736 in Measures of Political Attitudes, edited by John P. Robinson, Phillip R. Shaver and Lawrence S. Wrightman. San Diego: Academic Press.

Weßels, Bernhard. 2000. Gruppenbindung und Wahlverhalten: 50 Jahre Wahlen in der Bundesrepublik. Pp. 129-158 in 50 Jahre Empirische Wahlforschung in Deutschland. 
Entwicklung, Befunde, Perspektiven, Daten, edited by Markus Klein, Wolfgang Jagodzinski, Ekkehard Mochmann and Dieter Ohr. Wiesbaden: Westdeutscher Verlag. Wilson, Carole J. 2008. Consideration Sets and Political Choices: A Heterogeneous Model of Vote Choice and Sub-National Party Strength. Political Behavior 30(2): 161-83.

Zuckerman, Alan S. (ed.). 2005. The Social Logic of Politics: Personal Networks as Contexts for Political Behavior. Philadelphia: Temple University Press.

Zakharova, Maria, and Paul V. Warwick. 2014. The Sources of Valence Judgments: The Role of Policy Distance and the Structure of the Left-Right Continuum. Comparative Political Studies 47 (online pre-publication): 1-26.

Zuckerman, Alan S., Josip Dasovic and Jennifer Fitzgerald. 2007. Partisan Families. The Social Logic of Bounded Partisanship in Germany and Britain. Cambridge/Mass.: Cambridge University Press. 